\title{
Review
}

\section{Ocular blood flow and associated functional deviations in diabetic retinopathy}

\author{
L. Schmetterer ${ }^{1,2}$, M. Wolzt ${ }^{1}$ \\ ${ }^{1}$ Department of Clinical Pharmacology, University of Vienna \\ ${ }^{2}$ Institute of Medical Physics, University of Vienna
}

Keywords Diabetic retinopathy, ocular blood flow, retinal blood flow, choroidal blood flow, pathogenesis, hyperglycaemia, endothelial dysfunction, ocular blood flow techniques, validity, reproducibility.

Diabetic retinopathy is among the leading causes of blindness in the industrialised nations. The clinical course of diabetic retinopathy has been described in detail [1] and a grading system for the disease has been elaborated $[2,3]$. The mechanisms underlying this severe complication of Type I (insulin-dependent) and Type II (non-insulin-dependent) diabetes mellitus are, however, still not clear. Whereas some of the mechanisms which lead to proliferation in the late stages of retinopathy have been explained, the early processes, which lead to the onset of the disease are still obscure. Several hypotheses have been proposed including biochemical dysfunction linked to hyperglycaemia, oxidative stress, humoral or genetic factors, thickening of the capillary basement membrane and rheological and haemodynamic factors.

The concept that altered retinal blood flow may have a role in the development of diabetic retinopathy was emphasised more than 20 years ago. Since then haemodynamics of the retina in patients with di-

Corresponding author: L. Schmetterer, Ph.D, Department of Clinical Pharmacology, Währinger Gürtel 18-20, A-1090 Vienna; Austria

Abbreviations: IOP, Intraocular pressure; LDV, laser Doppler velocimetry; LDF, laser Doppler flowmetry; CDI, colour Doppler imaging; PSV, peak systolic velocity; EDV, end diastolic velocity; RI, resistance index; POBF, pulsatile ocular blood flow; FPA, fundus pulsation amplitude; DAG, diacylglycerol; PKC, protein kinase C; AGEs, advanced glycation end-products; NO, nitric oxide; NOS, nitric oxide synthase; LNMMA, $\mathrm{N}^{\mathrm{G}}$-monomethyl-L-arginine; VEGF, vascular endothelial growth factor; ACE, angiotensin converting enzyme; STZ, streptozotocin. abetes mellitus as well as in animal models of diabetes has attracted considerable research interest. Much less attention has been paid to the choroidal circulation in diabetes, which is surprising as much of the retinal oxygen is supplied from this vascular bed. In part this may arise from the difficulties in assessing choroidal blood flow in humans. A role for the choroidal circulation in the pathogenesis of diabetic retinopathy has been proposed previously, based on histological studies of the diabetic choroid [4-6]. Excessive basement membrane thickening in the choroid has been shown in human and experimental diabetes $[4,5]$.

The exact nature of ocular blood flow abnormalities in the different stages of diabetic retinopathy is still a matter of controversy. This may at least partially be caused by the variety of techniques used to assess haemodynamics of the eye. Hence we will briefly review the different techniques used to assess ocular haemodynamics in animals and humans and discuss results from clinical and animal studies in diabetes.

\section{Techniques for measurement of ocular blood flow}

\section{Anatomy and physiology}

The human eye is supplied by two separate vascular systems: the retinal blood vessels and the uveal blood vessels. The uveal vessels include the vascular beds of the iris, the ciliary body, and the choroid. The inner layers of the retina are nourished by the retinal vessels, whereas the outer retinal layers including the photoreceptors are nourished by the choroid [7]. In monkeys $65 \%$ of oxygen consumed by the retina is delivered by the choroid [8]. There are considerable differences between the fine structure of the retinal and the choroidal vasculature. Retinal capillaries 
have a diameter of 5 to $6 \mu \mathrm{m}$ only. The endothelial cells are surrounded by a basement membrane. Within this basement membrane there are a large number of intramural pericytes. Pericytes as well as endothelial cells are assumed to have an important role in the control of retinal blood flow. By contrast capillaries in the choroid are much wider and do not contain pericytes [7].

The perfusion rate in the choroid is much higher than in the retina. As blood flow is given by perfusion pressure:vascular resistance, the resistance of the retina is much higher than that of the choroid. The arteriovenous oxygen difference in the choroid is only $3-5 \%$, whereas the oxygen content in arterial blood of the retina is approximately $38 \%$ higher than in the veins. This could be related to the fact that the retinal vasculature shows a strong vasoconstrictor response to hyperoxia [9], whereas the choroid does not [10]. The response of a vascular bed to changes in arterial oxygen and carbon dioxide tension is sometimes referred to as autoregulation. It is preferable to define autoregulation, however, as the ability of a vascular bed to maintain blood flow despite changes in perfusion pressure. In its strict sense this behaviour can only be investigated in isolated organs, because in vivo experiments to alter ocular perfusion pressure always induce additional haemodynamic effects, regulation mechanisms or reflex responses, which may affect ocular perfusion. In humans artificial changes in intraocular pressure (IOP), isometric exercises and pharmacologically induced changes in blood pressure have been used to show that the retina has some autoregulatory capacity [11-14]. The autoregulatory capacity of the choroid by contrast is still a matter of debate $[7,15,16]$.

Considerable effort has been made to separately investigate these two vascular beds. Although some methods are capable of differentiating blood flow in these vascular beds, validation of results is difficult since a generally accepted criterion standard is not available. As in other vascular beds ocular blood flow is given as blood flow velocity multiplied by cross-sectional area. Some of the techniques described in this review only assess blood velocities. As cross-sectional area is not known in these cases interpretation of such data with respect to ocular blood flow should be made with caution. The same holds true if a technique only measures cross-sectional area when no information on flow velocity is available. We will briefly summarise the most important ocular blood flow techniques. For a more detailed review on ocular blood flow techniques the reader is referred to a recent article [17].

\section{Ocular blood flow techniques in humans}

Angiographic techniques. Fluorescein angiography was originally introduced by Novotny and Alvis [18]. This method has become an important clinical tool in the investigation of retinal blood flow, but normally only qualitative information can be extracted from the angiograms. Several attempts have been made to quantify retinal blood flow, whereby most approaches are based on the measurement of the time required for the dye to pass through the retinal circulation. Early techniques used densitometric measurements on photographic images of retinal vessels [19]. Relative concentrations of fluorescein in vessels of the retina are calculated for each consecutive picture. Dye dilution curves can then be derived for retinal arteries and veins. The mean retinal circulation time, defined as the difference between venous and arterial times, is inversely proportional to retinal blood velocity. If in addition retinal vessel diameters are measured an estimate of retinal blood flow can be derived. This technique has been adapted employing videoangiography [20-22] and scanning laser ophthalmoscopy [23-26]. The arterio-venous passage time, defined as the time between the first appearance of the dye in a retinal artery and in the corresponding vein [21], has been used to assess haemodynamics of the retina as an alternative to mean retinal circulation time.

Several limitations have to be considered when this method is applied to clinical or experimental studies [27]. Firstly, the technique assumes that all the blood of an area supplied by one specific artery is drained by the corresponding vein, which may not hold true in all cases. Secondly, the sum of all vessel diameters is thought to be directly related to retinal blood volume. Whereas this assumption is perhaps justified in normal subjects [27], in patients with diabetic retinopathy, where areas of retinal non-perfusion exist, this relation seems improbable. A third problem in diabetic patients arises from the leakage of fluorescein from retinal vessels, which is more severe in the later stages of retinopathy. Fourthly, vasodilation of the retinal vasculature increases the intravascular volume of distribution of the dye, which results in an increased mean circulation time without a change in blood flow. Fifthly, metabolic changes associated with diabetes may alter the fraction of protein bound fluorescein. Finally, an increased haematocrit may impair visualisation of the dye front.

An interesting approach to partially overcome these problems is targeted dye delivery [28]. In experimental animals a dye encapsulated in lipid vesicles is given intravenously and local release of the dye in the retina is achieved by a short heat pulse induced by laser light. Macular blood flow velocities have also been measured by tracking hyperfluorescent dots, assumed to represent leucocytes within the retinal vessels and hypofluorescent segments, assumed to pre- 
sent erythrocytes, as they pass through the perifoveal capillaries $[23,24,29]$, but doubts concerning the validity of this approach have been raised [30]. In addition, calculation of retinal blood flow is hampered because the diameters of the perifoveal capillaries cannot be determined. Techniques used in animal experiments to make leucocytes and erythrocytes visible have been developed by reinjection of blood cells stained ex vivo with fluorescent labels [31], which indicate that the speed of leucocytes in capillaries is considerably slower than that of erythrocytes [32]. Alternatively retinal leucocytes in animals can be made directly visible using intravenous injection of acridine orange [33].

Attempts have also been made to extract choroidal haemodynamic data from angiographic measurements; most of these techniques use indocyanine green as a dye. Several image processing techniques have been proposed to quantify choroidal blood flow [34-36], but the validity of these techniques is still to be shown. As in the retinal circulation it is possible to make leucocytes visible directly. This has been achieved using indocyanine green in albino rabbits [37]. Alternatively laser-targeted local dye delivery can also be used for making the blood flow in choriocapillaries visible [38].

Laser Doppler techniques. Another approach for quantifying retinal, optic disc, and choroidal blood flow is based on the optical Doppler effect. In laser Doppler velocimetry (LDV) a single retinal vessel is illuminated by a high coherence laser beam. This beam is scattered on the vessel wall as well as the moving erythrocytes. Hence the back-scattered light consists of light at the frequency of the incident light as well as of frequency shifted light. The power spectrum therefore consists of a range of frequency shifts corresponding to the flow velocities within the vessel under study. The maximum frequency shift corresponds to the maximum centre velocity within the vessel. Relative flow velocities in larger retinal vessels used to be measured in canine and human retinal vessels by means of this technique [39, 40]. Using bidirectional LDV an absolute determination of maximum centre blood velocities in retinal arteries and veins is possible [41]. From concomitant measurement of retinal vessel diameter, cross-sectional area volumetric blood flow can be calculated [42].

Calculation of total retinal blood flow from either arteries or veins using LDV in combination with retinal vessel size determination provides consistent results [42]. As mentioned above only the maximum centre velocity in retinal vessels can, however, be determined with this method. Quantitative information on the velocity profile in retinal arteries and veins cannot be extracted from the power spectrum. Hence the calculation of total retinal blood flow is based on a theoretical relation between maximum centre ve- locity and mean flow velocity within a vessel, which has not yet been verified in vivo. An unresolved issue with retinal LDV is that Riva and co-workers [42] determined a total retinal blood flow of approximately $35 \mu \mathrm{l} / \mathrm{min}$ in healthy subjects, whereas Feke et al. [43] found $80 \mu \mathrm{l} / \mathrm{min}$ in a similar study cohort using a different instrument for measurement of the power spectra. Several procedures have been proposed for the measurement of retinal vessel diameters [44-47]. Obviously an accurate determination of arterial and venous diameter is of critical importance for the calculation of total volumetric blood flow.

Laser Doppler techniques can also be used to gain information on optic disc and choroidal blood flow. Based on the theory of light scattering in tissue [48] blood flow in the optic disc [49] and the choroid [15, $50,51]$ can be measured in relative units (laser Doppler flowmetry, LDF). This theory [48] assumes that vascularised tissue is illuminated by coherent laser light. Scattering on moving erythrocytes leads to a frequency shift in the scattered light. In contrast, static scatterers in tissue do not change light frequency but lead to randomisation of light directions impinging on erythrocytes. This light diffusing in vascularised tissue leads to a broadening of the spectrum of scattered light. Assuming that scattering on the tissue matrix leads to a total randomisation of light directions impinging on erythrocytes the mean corpuscular velocity, the blood volume and the blood flow can be calculated from the Doppler shift power spectrum in relative units. Although LDF in the human choroid is currently restricted to the region where the retina lacks vasculature, this method has considerable potential for the investigation of this vascular bed [16]. The relative contribution of different capillary layers in the optic disc and the choroid to the Doppler signal is still, however, to be clarified. In addition it has not yet been shown that all assumptions of the underlying theory are substantiated in these vascular beds. Optic disc blood flow has also been investigated evaluating blood speed with LDV and blood volume with fundus reflectometry [52].

Scanning laser Doppler flowmetry combines the principles of LDF with laser scanning tomography [53]. The commercially available Heidelberg retina flowmeter can be used to investigate retinal and optic disc blood flow. During the laser scanning process the haemodynamic variables are calculated from the backscattered light for each point. Hence a two-dimensional mapping of retinal and optic disc blood flow can be obtained. The limitations of single point LDF mentioned above also hold true for scanning laser Doppler flowmetry. In addition, it has been shown that the instrument has a considerable zero set-off [54]. Information on very high and very low blood speeds are possibly lost with this system because the frequency band used for detection of the Doppler shifts is narrow $(125-2000 \mathrm{~Hz},[55])$. 
Colour Doppler imaging. The Doppler shift can also be used to gain information on blood velocities in extraocular vessels [56]. This technique is normally referred to as colour Doppler imaging (CDI). Doppler spectra can be obtained from the central retinal arteries, the posterior ciliary arteries and the ophthalmic artery. Peak systolic velocity (PSV), end diastolic velocity (EDV) and mean flow velocity are determined with this technique. The resistance index (RI) is calculated as RI $=(\mathrm{PSV}-\mathrm{EDV}) / \mathrm{PSV}$ and has been proposed as a measure of distal vascular resistance for organs that constantly demand oxygen such as the brain and the eye [57]. Interpretation of RI as an indicator of vascular resistance has, however, to be made with caution [58] particularly in pharmacodynamic studies [59]. One important limitation of CDI is that no quantitative information on vessel diameter is obtained. Hence calculation of total blood flow is not possible with this method. Consequently it is often difficult to decide whether an increase in blood velocities reflects an increase in blood flow through the artery or a constriction of the vessel.

Blue field entoptic technique. This method for the investigation of leucocyte dynamics in retinal perifoveal vessels is based on the entoptic phenomenon $[60,61]$. The blue field entoptic phenomenon can be seen best by looking into a blue light with a narrow optical spectrum at a wavelength of approximately $430 \mathrm{~nm}$. Under these conditions many tiny corpuscles can be seen flying around swiftly in an area of 10 to 15 degrees of arc radius centred at the fovea. Most probably the underlying phenomenon is that erythrocytes, but not leucocytes absorb short wavelength light. Thus the passage of a leucocyte is perceived as a flying corpuscle. For determination of retinal haemodynamic variables a simulated particle field is shown to the subjects under study. By comparison with their own entoptic observation subjects can adjust the number of leucocytes, the mean flow velocity and the pulsatility of motion, from which the retinal blood flow and the flow pulsatility can be calculated. An important limitation of this technique is its subjective nature. Because of fatigue, the reproducibility of the method is often poor when repeated measurements are done in one subject. In addition, subjects with poor visual acuity are unable to see their own leucocytes in blue light. Whether measurement of leucocyte velocity and density is a valid indicator of blood flow abnormalities in diabetes is still to be established.

Laser speckle technique. Another possibility for investigating the retinal microcirculation is the use of the laser speckle phenomenon [62,63]. Laser speckle is an interference phenomenon that can be observed when coherent light is scattered from a rough surface. When the ocular fundus is illuminated the structure of the pattern varies rapidly. The rate of variation depends on the erythrocyte velocity and can therefore be used to quantify blood speed. Briers and Fercher [62] developed a semi-quantitative method for the mapping of human retinal blood flow based on laser speckle photography. Tamaki et al. [63] presented an apparatus for the assessment of retinal blood velocities in rabbits using an image sensor. Choroidal and optic nerve head blood velocities have also been investigated with this method [64]. As vessel diameter cannot be measured, calculation of volumetric blood flow is not possible with this method. To date no data on haemodynamics of the eye in diabetes are available using this method, but it could have considerable potential in the future.

Pulsatile ocular blood flow techniques. Assessment of pulsatile ocular blood flow (POBF) has been proposed by using pneumotonometry [65] and laser interferometric measurement of ocular fundus pulsation [66]. Pneumotonometry measures changes in intraocular pressure (IOP) during the cardiac cycle. When the inflow of blood through the ocular arteries exceeds the outflow through the ocular veins, the ocular volume and the intraocular pressure increases. The maximum IOP change during a heart cycle is called pulse amplitude. The relation between changes in intraocular pressure and changes in intraocular volume depends on the scleral rigidity, which characterises the mechanical properties of the eye coats. A method for the calculation of POBF from the time course of IOP changes during the heart cycle, which is based on a hydrodynamic model eye assuming a standard ocular rigidity for all eyes and a non-pulsatile outflow of blood through the ocular veins has been developed [65]. Whether this is justified in vivo is not entirely clear.

Alternatively, POBF can be assessed by measuring distance changes between cornea and retina during the cardiac cycle $[66,67]$. This phenomenon is called ocular fundus pulsation and the maximum distance change during the cardiac cycle is called fundus pulsation amplitude (FPA). The distance between cornea and retina decreases during the systole and increases during the diastole. Compared to pneumotonometry the method provides a more direct measure of ocular volume change. Fundus pulsation amplitude is, however, a local measure because the parallel laser beam which is used to illuminate the eye is focused on the retina. This enables investigation of ocular blood flow with a high spatial resolution but hampers calculation of total POBF. Nevertheless there is a high association between pneumotonometrically determined POBF and FPA in the macula [68]. In monkeys blood flow through the choroid as well as blood volume in the choroid is much higher than in the retina $[7,8]$. Hence it is conceivable that POBF and FPA are almost exclusively influenced by choroi- 
Table 1. Techniques for the assessment of haemodynamics of the eye in humans

\begin{tabular}{|c|c|c|c|c|c|c|}
\hline Technique & References & $\begin{array}{l}\text { Measured } \\
\text { variable }\end{array}$ & $\begin{array}{l}\text { Vascular } \\
\text { bed }\end{array}$ & $\begin{array}{l}\text { Measurement } \\
\text { location }\end{array}$ & $\begin{array}{l}\text { Main } \\
\text { limitations }\end{array}$ & $\begin{array}{l}\text { Financial } \\
\text { requirements }\end{array}$ \\
\hline $\begin{array}{l}\text { Fluorescein } \\
\text { angiography }\end{array}$ & 20,22 & $\begin{array}{l}\text { Mean circulation } \\
\text { time }\end{array}$ & Retina & $\begin{array}{l}\text { Main retinal } \\
\text { vessels }\end{array}$ & $\begin{array}{l}\text { Exact relation to } \\
\text { retinal blood flow } \\
\text { unclear }\end{array}$ & High \\
\hline $\begin{array}{l}\text { Fluorescein } \\
\text { angiography }\end{array}$ & 21 & $\begin{array}{l}\text { Arterio-venous } \\
\text { passage time }\end{array}$ & Retina & $\begin{array}{l}\text { Main retinal } \\
\text { vessels }\end{array}$ & $\begin{array}{l}\text { Exact relation to } \\
\text { retinal blood flow } \\
\text { unclear }\end{array}$ & High \\
\hline $\begin{array}{l}\text { Laser Doppler } \\
\text { velocimetry com- } \\
\text { bined with Fundus } \\
\text { photography }\end{array}$ & 41,42 & Blood flow & Retina & $\begin{array}{l}\text { Main retinal } \\
\text { vessels }\end{array}$ & $\begin{array}{l}\text { Skilled operator } \\
\text { necessary }\end{array}$ & Very high \\
\hline $\begin{array}{l}\text { Colour Doppler } \\
\text { imaging }\end{array}$ & 56 & Blood velocities & $\begin{array}{l}\text { Central retinal } \\
\text { artery, posterior } \\
\text { ciliary arteries, } \\
\text { ophthalmic artery }\end{array}$ & $\begin{array}{l}\text { Extraocular } \\
\text { vessels }\end{array}$ & $\begin{array}{l}\text { No information on } \\
\text { vessel diameter }\end{array}$ & Very High \\
\hline $\begin{array}{l}\text { Blue field entoptic } \\
\text { technique }\end{array}$ & 60 & $\begin{array}{l}\text { Leucocyte velocity } \\
\text { and density }\end{array}$ & Retina & $\begin{array}{l}\text { Perimacular } \\
\text { retinal capillaries }\end{array}$ & $\begin{array}{l}\text { Leucocyte move- } \\
\text { ment } \neq \text { blood flow, } \\
\text { subjective }\end{array}$ & Low \\
\hline $\begin{array}{l}\text { Pneumotono- } \\
\text { metry }\end{array}$ & 65 & $\begin{array}{l}\text { Changes in intra- } \\
\text { ocular pressure } \\
\text { during cardiac cycle }\end{array}$ & Choroid (mainly) & Global & $\begin{array}{l}\text { Only pulsatile flow } \\
\text { component, stand- } \\
\text { ard ocular rigidity } \\
\text { assumed }\end{array}$ & Low \\
\hline
\end{tabular}

dal blood flow. An important limitation of both methods is that only the pulsatile component of blood flow is assessed. The pulsatile fraction of choroidal blood flow has not yet been determined in humans. Estimates vary between 0.5 [69] and 0.8 [70].

\section{Invasive ocular blood flow techniques in animals}

Several methods for the investigation of ocular blood flow have been developed, but these cannot be applied in humans due to their invasive nature. Radioactively labelled microspheres have widely been used to measure blood flow in the retinal as well as in the uveal vasculature [71]. Microspheres are injected into the left ventricle of the heart. Radiographic measurement of microsphere density in the tissue of interest allows estimation of blood flow after the animal has been killed. In tissues with low flow rates such as the retina the small number of spheres trapped in the tissue sample limits the sensitivity of the method. The limitations of the method for choroidal perfusion studies have recently be summarised by Kiel [72]. In the optic nerve head, blood flow has also been determined with coloured microspheres [73].

\section{Summary}

All of the above-mentioned methods have considerable limitations for the assessment of ocular blood flow. The choice of an optimal method for the assessment of haemodynamics of the eye is dependent on the aim underlying the study as well as on the design and the study group included. In particular the reproducibility and the sensitivity of each method has to be taken into consideration. For some of the abovementioned methods specific investigations on these variables exist $[42,53,55,61,68,74-79]$, whereas they have received little attention in other techniques (Table 1). 


\section{Clinical and experimental studies of ocular blood flow in diabetes}

\section{Effect of diabetes on ocular blood flow in humans}

Fluorescein angiographic studies. One of the first hints of altered retinal blood flow in patients with diabetes mellitus came from Kohner et al. [80]. Based on measurements of mean retinal circulation time from fluorescein angiograms they reported increased retinal blood flow in patients with absent or mild, but not with moderate or severe diabetic retinopathy. Increased retinal blood flow in the early stages of retinopathy and decreased retinal blood flow in proliferative retinopathy was also assumed based on fluorophotometry, a method related to fluorescein angiography $[81,82]$. By contrast, Blair et al. [83] did not observe an alteration of mean retinal circulation time in early retinal damage but reported prolongation in proliferative retinopathy using a modified fluorescein dye dilution technique. Yoshida et al. [84] confirmed these earlier reports of decreased mean circulation time and reported increasing blood flow with the progression of background diabetic retinopathy. Conversely, increased arteriovenous passage time was generally observed in patients with long-standing Type I diabetes using a video fluorescein device [85]. In Type I diabetic patients with no apparent retinopathy Bursell et al. [86] reported an increased mean circulation time indicative of reduced retinal blood flow. With advancing non-proliferative retinopathy the same group found a sequential decrease in mean circulation time [87].

Several studies have focused on flow velocities in perimacular capillaries using a scanning laser ophthalmoscope. Generally, a reduction in flow velocities was observed in diabetic patients [23, 29]. This reduced retinal capillary flow velocity is possibly associated with impaired rheological properties of blood [88]. Patients with Type II diabetes also have reduced perifoveal blood velocities as well as increased perifoveal intercapillary areas in the foveal avascular zone [89]. Increased perifoveal intercapillary area and the area of avascular zone show a negative association with visual acuity [90] and contrast sensitivity in diabetic patients [91].

Laser Doppler velocimetry studies. Most data on retinal blood flow in diabetes are available from LDV studies. As mentioned above the technique has only few limitations and therefore much of our knowledge on retinal perfusion abnormalities derives from these investigations. It has been shown by numerous investigators that patients with diabetic retinopathy have increased venous and arterial vessel diameters [92-97]. Blood velocities in retinal veins considerably decrease, however, with progression of diabetic retinopathy [93]. As total blood flow is dependent on the cross-sectional area of the vessel as well as on flow velocity the authors did not find any alterations in total retinal blood flow. The same group described that in patients with background retinopathy under poor glycaemic control, total venous cross-section and volumetric blood flow rate was increased [94]. A study of retinal blood flow in a large cohort of patients with diabetic retinopathy has been done by Patel et al. [95]. Increased retinal vessel diameter was observed in patients with background, preproliferative, and proliferative retinopathy, but not in diabetic patients without retinopathy. By contrast, maximum erythrocyte velocity was not dependent on the stage of retinopathy. As a consequence total retinal blood flow increased with progression of the disease, showing highest values in patients with proliferative retinopathy. In patients with proliferative retinopathy haemodynamics of the retina depend, however, on the specific pathologic features [98]. Severe capillary nonperfusion and vessel staining were associated with reduced retinal blood flow. By contrast, the authors observed pronounced venous vasodilation in patients with macular oedema.

Another LDV study focused on retinal flow pulsatility defined as systolic flow velocity:diastolic flow velocity in patients with Type I diabetes. Compared with healthy subjects flow pulsatility was lower in patients with background retinopathy but higher in patients with proliferative retinopathy [92]. The same group reported reduced blood speed, increased arterial cross-section and reduced retinal blood flow in Type I diabetic patients with no or background retinopathy [96]. A shift from decreased to increased retinal blood flow was, however, observed with progression of the disease [99]. One potentially confounding factor of these studies is that only a single artery was used for assessment of haemodynamics of the retina [100].

A recent study has shown that retinal perfusion is already increased in patients with early Type I diabetes with a diabetes duration of less than 4 years [101]. None of the diabetic patients under study had any clinical sign of retinopathy. Nevertheless vessel diameter as well as total retinal blood flow was increased in this study group as compared with a healthy control group matched for age. Other results [97] also indicate that retinal vasodilation may precede development of other signs of retinopathy.

Colour Doppler imaging studies. A rise in RI in the ophthalmic artery, which is possibly indicative of an increase in distal vascular resistance, has been observed in diabetic patients with different degrees of retinopathy [102]. An increase in RI along with a reduction in arterial flow velocities has also been observed in the central retinal artery in patients with proliferative retinopathy [103]. By contrast, Goebel et al. [104] observed no alterations in the haemody- 
namics of the ophthalmic artery in diabetic patients but reported a decrease in blood speed in the central retinal arteries, which was more pronounced in the late stages of retinopathy. Interestingly, central retinal artery flow velocity appears to be reduced before the clinical onset of diabetic retinopathy [105]. Several authors interpreted these results as a sign of decreased retinal perfusion in diabetic patients. It should, however, be considered that reduced flow velocity in extraocular vessels may arise from diabetesinduced vasodilation and any estimation of total retinal blood flow from these results is therefore not valid.

Knowledge on the choroidal circulation in diabetes arises from CDI studies of the posterior ciliary arteries. Both reduced [103] and unchanged [104] flow velocities in these arteries supplying the choroid have been observed in diabetic compared with healthy control subjects.

Blue field entoptic studies. In patients with background diabetic retinopathy leucocyte velocity in the perifoveal capillaries is higher than in normal control subjects [106]. In the preproliferative group leucocyte velocity was reduced, whereas patients with proliferative retinopathy had normal leucocyte velocities in the retina. In a longitudinal study with a mean observation period of more than 30 months patients with background and preproliferative retinopathy had a fall in retinal leucocyte velocity within the study period [107]. Patients with Type I diabetes have a $25 \%$ increase in leucocyte capillary flow velocity along with a $37 \%$ reduction in the density of leucocytes [108]. The reduction in leucocyte density was more pronounced in diabetic patients with retinopathy, but was poorly associated with the degree of the disease. Comparing these results with other clinical trails it has to be considered that erythrocyte and leucocyte velocities are different in retinal capillaries [32]. Moreover, diabetes does not necessarily influence leucocyte and erythrocyte velocity to a similar degree [100].

Pulsatile ocular blood flow studies. The results of pneumotonometric studies on pulsatile ocular blood flow in diabetes are contradictory. Langham et al. [109] observed a strong reduction in POBF in patients with proliferative retinopathy compared with normal subjects, but this result was not confirmed by others. Becker et al. [110] observed no impact of diabetic retinopathy on POBF. By contrast, MacKinnon et al. [111] observed higher POBF values in diabetic than in control subjects. Using laser interferometric measurement of fundus pulsation Schmetterer et al. [112] found a small reduction in fundus pulsation amplitude in proliferative retinopathy but no change in the early stages of the disease. All POBF studies in patients with diabetes are hampered because flow pulsatility is possibly altered in the diabetic choroid. Altered flow pulsatility in the retina [96] and evidence for altered choroidal vascular rigidity in patients with Type I diabetes [113] support this assumption.

\section{Effect of interventions}

Glycaemic control. Several reports indicate that glycaemic control has an important impact on retinal perfusion. It has been shown in angiographic studies that $\mathrm{HbA}_{1 \mathrm{c}}$ is correlated with arteriovenous passage time in adults with Type I [85] and patients with Type II diabetes [114]. The effect of institution of strict diabetic control has been investigated using the LDV technique. This is of special interest because soon after commencing intensified insulin therapy some eyes show a rapid progression of retinopathy $[1,115,116]$. A lack of decrease in retinal blood flow 5 days after institution of strict diabetic control has been associated with progression of retinopathy [117-119].

Effect of hyperoxia and autoregulation. The retinal blood flow response to experimental hyperoxia, measured with LDV, is considerably reduced in patients with diabetes $[9,94,120]$. This reduction in the response to oxygen breathing is correlated with the degree of retinopathy [94]. An abnormal response to hyperoxia in diabetic patients was also evident in a colour Doppler imaging study in the central retinal artery and the ophthalmic artery [121]. By contrast, Fallon et al. [122], using the blue field technique, observed a blunted response to hyperoxia in patients with non-proliferative retinopathy only.

The first evidence of altered retinal autoregulation in diabetic patients came from Sinclair et al. [123] who used the blue field technique after a rapid reduction in intraocular pressure. Retinal autoregulation in diabetic patients was also investigated in a LDV study inducing an increase in blood pressure by treatment with tyramine [13]. An impairment in retinal vascular autoregulation was observed, which was more pronounced during hyperglycaemia than during normoglycaemia. Whether impaired autoregulation in diabetes is simply due to altered retinal basal tone associated with the disease is not known.

Effect of photocoagulation. It has unequivocally been shown that panretinal photocoagulation leads to a reduction in retinal blood flow and a reduction in retinal vessel diameter. This has been shown by means of LDV [124, 125], fluorescein angiography [126], and measurement of retinal vessel diameter [127]. This reaction of the retinal vasculature to panretinal photocoagulation could be caused by an improvement in retinal oxygenation. This hypothesis is further supported by the restoration of the retinal response to experimental hyperoxia after panretinal 
Table 2. Haemodynamics of the retina in patients with diabetes ${ }^{\mathrm{a}}$

\begin{tabular}{llll}
\hline Stage $^{\mathrm{b}}$ & Velocity & Cross-sectional Area & Blood flow \\
\hline No retinopathy & Normal/slightly reduced & Slightly increased & Slightly increased \\
Background retinopathy & Normal/reduced & Increased & Increased \\
Pre-proliferative retinopathy & Normal/reduced & Increased & Increased \\
Proliferative retinopathy & Dependent on the clinical features & & \\
\hline
\end{tabular}

a See references 23, 29, 93-95, 98, 101, 104

$\mathrm{b}$ The staging of diabetic retinopathy is not identical in all ocular haemodynamic studies. An investigation relating retinal blood flow to the stages of the modified Airlie house classification $(2,3)$ is still lacking photocoagulation [124]. Regional laser treatment produces only regional reduction in blood flow [128]. In eyes showing progression of retinopathy despite photocoagulation no improvement in the retinal response to hyperoxia was observed [125]. Interestingly Bertram et al. [129] reported increased blood velocity based on measurements of arteriovenous passage time in response to panretinal photocoagulation. In view of the above mentioned results this increased blood speed could, however, reflect vasoconstriction rather than an increase in retinal blood flow. Arterial and venous vasoconstriction as well as an improvement in retinal oxygenation has also been observed in response to laser treatment for diabetic macular oedema [130, 131]. Panretinal photocoagulation reduces POBF [132], which indicates that choroidal blood flow falls after treatment in proliferative retinopathy. This is of importance because measurements of panretinal oxygen tension in monkeys indicate that the therapeutic effect underlying panretinal photocoagulation may lie in improved retinal oxygenation from the choroid [133].

\section{Effect of diabetes on ocular blood flow in animals}

A variety of animal models of diabetes have been proposed, which have greatly enhanced our understanding of the mechanisms underlying the disease. It is still, however, not clear whether ocular haemodynamic alterations in these animal models are relevant to those in humans as the existence of important differences between species cannot be ruled out. Nevertheless, as assessment of haemodynamics of the eye in experimental animals is easier than in humans due to the applicability of invasive methods, several animal studies have been done to explain ocular blood flow abnormalities in diabetes. In addition, a number of studies have focused on the effect of potential therapeutic drugs on normalisation of diabetes-induced haemodynamic alterations.

In streptozotocin (STZ) diabetic rats mean circulation time is increased [22, 87, 134-136], which is possibly indicative of reduced retinal blood flow. A prolongation of mean circulation time has also been observed in spontaneous diabetic Goto-Kakizaki rats, a model Type II diabetes [25]. Normalisation of retinal blood flow in STZ-induced diabetic rats was achieved, when strict glycaemic control was initiated using insulin pumps [134]. Prevention of abnormal retinal blood flow induced by diabetes has also been reported using acarbose, an $\alpha$-glucosidase inhibitor [135].

The data of this study group are quite different from the observations of increased retinal blood flow in STZ-induced diabetic rats as evidenced from hydrogen clearance polarography [137]. Increased blood flow to the retina and choroid in STZ-induced diabetic rats has also been shown using radioactively labelled microspheres [138-140]. Interestingly, this study showed that choroidal blood flow is also increased in rats treated with a single injection of nicotinamide, which induces a very mild form of diabetes [138]. Impaired ocular vasoactivity to noradrenaline, adrenaline, phenylephrine, prostaglandin $\mathrm{F}_{2 \alpha}$, and 5hydroxytryptamine has been shown in the perfused eye of diabetic rats [141]. In a small group of alloxan-induced diabetic dogs, retinal blood flow assessed with radioactively labelled microspheres was reduced compared with healthy dogs [142].

A decrease of choroidal blood flow after photocoagulation has also been shown in animal experiments using radioactively labelled microspheres in monkeys [143]. Aricidine orange digital fluorography was used to investigate the effect of scatter photocoagulation on leucocyte velocity in rats [144]. Immediately after photocoagulation leucocyte velocities were reduced but restored 28 days later.

\section{Summary}

There is evidence from a variety of studies that retinal vasodilation occurs before the clinical onset of retinopathy in patients with diabetes. Increased ocular blood flow is observed in patients with background retinopathy. In the late stages of diabetic retinopathy the nature of ocular perfusion abnormalities appears to strongly depend on glycaemic control as well as on the specific pathologic features. An overview of retinal perfusion abnormalities in the different stages of retinopathy (Table 2) does, however, not as yet re- 
flect general acceptance because some studies have contradictory results.

\section{Pathophysiology of ocular blood flow abnormalities in diabetic retinopathy}

\section{The role of hyperglycaemia}

There is conclusive evidence from the Diabetes Control and Complication Trial [115] that hyperglycaemia has a key role in the development of vascular complications in diabetes. This is supported by dog experiments, which indicate that euglycaemia can almost prevent the onset of diabetic retinopathy if it is achieved early after the onset of diabetes [145, 146]. By contrast, dogs that were under poor glycaemic control for 30 months and then switched to euglycaemia for 30 months developed considerable retinopathy although no retinopathy had been apparent after 30 months in poor control. Hence, hitherto unidentified retinal metabolic changes induced by hyperglycaemia in diabetes eventually lead to retinopathy even if euglycaemia is achieved subsequently by intensified insulin treatment. The results of this animal experiment as well as the human epidemiological data indicate that life-time exposure to hyperglycaemia is a major determinant of diabetic retinopathy.

Animal studies in cats [147], dogs [148], minipigs [149], normal rats [150], and in STZ-diabetic rats $[139,140]$ show that short-term hyperglycaemia induces a pronounced increase in retinal blood flow, whereas short-term hypoglycaemia decreases retinal blood flow [151]. In patients with Type II diabetes an insulin-induced reduction in blood glucose leads to a reduction in retinal blood flow assessed with LDV [152]. In addition, normoglycaemia increased the retinal vascular response to hyperoxia, although the response was still impaired [120, 152]. Bursell et al. [86] measured mean retinal circulation times during hyperglycaemic clamp experiments. Their results indicate that retinal blood flow is strongly dependent on glucose plasma concentrations and that a twofold increase in blood glucose leads to an increase in retinal perfusion. All the above-mentioned studies focused on the effect of short-term hypoglycaemia or hyperglycaemia on haemodynamics of the eye. The effects on prolonged hyperglycaemia are still, however, to be established.

As hyperglycaemia appears to be the primary factor in the development of diabetic retinopathy, special emphasis has been directed to the secondary metabolic pathways that lead to vascular dysfunction in diabetes. It is now apparent that several intracellular alterations are induced by glucose in the retina. The importance of these potential secondary factors, which include effects on the sorbitol pathway, non- enzymatic glycation, the nicotinamide adenine dinucleotide redox status (NADH:NAD ${ }^{+}$), the diacylglycerol/protein kinase C (DAG/PKC) pathway, endothelial function, and protein expression is still to be established.

The sorbitol pathway. Glucose can be converted to sorbitol by aldose reductase in retinal cells [153]. During hyperglycaemia this may lead to intracellular accumulation of sorbitol. Experimental modulation of this specific pathway is possible because other aldose sugars such as galactose, which are normally not involved in the glucose metabolism, can be used as competitive substrates for aldose reductase. For example, feeding galactose to non-diabetic animals produced diabetic-like retinopathy in several experiments [154-155], which suggests a role of sorbitol accumulation in the development of diabetic retinopathy. Hence aldose reductase inhibitors, such as sorbinil, which have been reported to prevent retinopathy in animal models [156] can theoretically be useful for prevention of diabetic complications. A clinical trial did not show effective treatment by sorbinil in diabetic patients [157]. It has, however, been argued that the observation period in this clinical trial was not sufficiently long to be conclusive [1] and that the dose used was not adequate to normalise flux through this pathway. Hence, the results of long-term clinical outcome studies are required to gain conclusive information.

The first evidence of an involvement of the polyol pathway in the increase of ocular blood flow came from the observation that galactose-fed rats develop an increase in retinal blood flow similar to diabetic rats [158]. Moreover, this increase in ocular perfusion induced by galactose-enriched diets was prevented by treatment with sorbinil. The same group showed that in STZ-induced diabetic rats aldose reductase inhibitors prevent ocular hyperperfusion, retinal albumin permeation and the concomitant increase in regional haematocrit $[139,140]$.

Non-enzymatic glycation. In the circulating blood, haemoglobin and other lysine-containing proteins are glycated through a non-enzymatic reaction of glucose with lysine [159]. This leads to irreversible formation of advanced glycation end-products [AGEs, 160], which is assumed to have a role in the development of diabetic retinopathy [161]. Aminoguanidine, which has been shown to retard the formation of AGEs [162], seems to inhibit the development of experimental diabetic retinopathy [161], although some concerns regarding this study have been raised [1]. Importantly, aminoguanidine also acts via inhibition of nitric oxide (NO) formation [163], which will be discussed below. Hence, a possible role of AGEs in the control of ocular blood flow is difficult to assess on the basis of these studies because the normalisa- 
tion of ocular blood flow in aminoguanidine-treated rats is mainly ascribed to the NO-synthase inhibiting properties of the drug [164].

NADH:NAD ${ }^{+}$redox status. The ratio of $\mathrm{NADH}: \mathrm{NAD}^{+}$is also partially coupled to the sorbitol pathway. As mentioned above glucose is first reduced to sorbitol and then slowly oxidised to fructose by sorbitol dehydrogenase. This may lead to an increased ratio of the cofactor of this reaction NADH:NAD ${ }^{+}$, which could further be enhanced due to increased oxidation of non-esterified fatty acids and glucuronic acid pathway metabolites [165]. Normalisation of the NADH:NAD ${ }^{+}$ratio with pyruvate prevents the hyperglycaemia-induced increase in ocular blood flow [150]. This redox imbalance promotes free radical production including superoxide, which is assumed to induce vasodilation by several pathways [166]. A change in NADH:NAD ${ }^{+}$ratio is also induced by hypoxia and ischaemia but the glucose induced reductive stress appears to be independent of tissue oxygenation, which prompted Williamson et al. [165] to call this phenomenon pseudohypoxia. The pseudohypoxia hypothesis [167] was recently challenged by the experiments of Winkler et al. [168] and the issue is still a matter of controversy [169].

The DAG/PKC pathway. The activation of PKC by hyperglycaemia in diabetes mellitus is related to the increase of DAG, an activator of $\mathrm{PKC}$, and regulates a number of vascular functions including vascular permeability, basement membrane synthesis and smooth muscle cell contractility. Diacylglycerol can be activated from a number of pathways, which have recently been reviewed [170]. Activation of PKC, in particular the isoforms $P K C \beta_{1}$ and $P K C \beta_{2}$, in parallel with increased $\mathrm{PKC}$ concentrations, has been shown in the rat retina [171].

High dose d- $\alpha$-tocopherol (vitamin E) treatment has been shown to normalise altered retinal mean transit time in STZ-induced diabetic rats via normalisation of hyperglycaemia-induced activation of the DAG/PKC pathway [172]. Preliminary data indicate that vitamin $\mathrm{E}$ may also decrease mean circulation time in patients with Type I diabetes [173]. Normalisation of abnormal haemodynamics of the retina along with a reduction of PKC activation was also observed when STZ-induced diabetic rats were treated with a specific inhibitor of the $\beta$-isoform of PKC [174]. Increased retinal blood flow in STZ-induced diabetic rats, as determined by microsphere experiments, was reduced after treatment with an inhibitor of transcription factor binding to specific PKC-regulated genes [175]. Curiously the investigators using video-based fluorescein angiography refer to normalisation in rat retinal blood flow when a drug increases blood flow of diabetic rats towards levels they observe in normal rats. Other research groups, however, using the microsphere technique refer to normalisation of retinal blood flow if a drug is able to reduce the increased retinal blood flow in diabetic rats. Obviously there is a need to clarify the exact nature of retinal perfusion abnormalities in STZ-induced diabetic rats. Further experiments using both techniques in the same group of rats are required in order to explain whether these differences are caused by methodological problems in assessing haemodynamics of the retina, by differences in animal preparation or by the duration of diabetes.

\section{The role of insulin and $C$-peptide}

Insulin. The absence of endogenous insulin has been shown to be unrelated to the frequency or severity of diabetic retinopathy [176]. Insulin has, however, recently been discovered as a direct vasodilator independent of tissue metabolism [177]. This vasodilator action is at least partially dependent on NO [178], most likely via stimulation of the constitutive form of NO synthase (NOS) [179].

Insulin also increases choroidal blood flow in humans by a NO dependent mechanism [180]. Direct vasodilator action of insulin has been observed in isolated retinal arteries [181]. To what extent insulin regulates retinal blood flow in man is still to be explained.

C-peptide. For a long time it has been assumed that the only biological action of C-peptide resides in its function as a split-off product in the breakdown of proinsulin. Thus, C-peptide plasma concentrations have been shown to be unrelated to the incidence and progression of diabetic retinopathy [182]. There is, however, recent evidence that treatment with $\mathrm{C}$ peptide prevents increased retinal blood flow in STZ-induced diabetic rats [183]. Its role in ocular blood flow regulation as well as its potential therapeutic effectiveness is, however, still to be further established.

\section{The role of tissue hypoxia}

It has been observed in clinical studies that areas of capillary non-perfusion are associated with the development of neovascular proliferation [184]. This is possibly related to regional tissue hypoxia associated with capillary loss. The first haemodynamic evidence for a hypoxic retina came from the altered retinal response to hyperoxia in diabetic patients [9]. This concept is supported by the finding that experimental hyperoxia improves contrast sensitivity in patients with early diabetic retinopathy [185]. In addition, there is recent evidence that oxygen consumption is increased in early streptozotocin-induced diabetes in 
the rat [186], which in turn may lead to retinal hypoxia. Whether increased retinal blood flow in early stage diabetic retinopathy is related to tissue hypoxia is still, however, to be established.

\section{The role of impaired blood rheology}

Several reports indicate that blood rheological factors are impaired in patients with diabetes. Increased plasma viscosity or increased erythrocyte rigidity has been observed in Type I as well as in Type II diabetes $[88,187,188]$. These factors have been hypothesised to contribute to altered retinal blood flow in patients with Type II diabetes [88]. In STZ-induced diabetic rats haematocrit in arterial blood samples was no different from normal but regional haematocrit was altered in ocular tissues [140]. A direct association between alterations in blood rheology and altered ocular perfusion has, however, not yet been established.

\section{The role of endothelial dysfunction}

Increased ocular blood flow and endothelial dysfunction. The observation that retinal perfusion abnormalities are detectable in diabetic patients with no clinical sign of retinopathy $[29,101]$ further supported the hypothesis that increased retinal blood flow itself may have a pathogenic role in diabetic retinopathy. In general there is overwhelming evidence that retinal blood flow is increased in diabetic retinopathy $[100,189]$. This high level of retinal perfusion is assumed to induce endothelial damage due to increased shear stress [189]. Altered retinal autoregulation may contribute to endothelial damage as induced by retinal hyperperfusion. This hypothesis agrees with the observation that systemic hypertension increases the frequency and rate of progression of diabetic retinopathy [190].

Nitric oxide. Nitric oxide, which is synthesised by the vascular endothelium from its precursor L-arginine, is a potent vasodilator [191]. The oxidation of L-arginine to form L-citrulline and NO is catalysed by nitric oxide synthase (NOS).

Altered endothelium-dependent vasodilation has been observed in animal models of Type I [192] and Type II diabetes, although the exact nature of the abnormalities in the latter group remains controversial [193, 194]. In humans altered reactivity to $\mathrm{N}^{\mathrm{G}}$ monomethyl-L-arginine (L-NMMA), an L-arginine analogue that acts as an inhibitor of NOS, was first observed in the forearms of patients with Type I and patients with Type II diabetes [195, 196]. More recently it has been shown that patients with Type I diabetes also have a reduced systemic pressor effect to intravenous L-NMMA [197]. The reason for this altered response to NOS inhibitors is still a subject of controversy. Several mechanisms including increased and decreased basal NO production and altered NO sensitivity have been assumed to contribute to this phenomenon. A detailed discussion of our current understanding of endothelial nitric oxide signalling dysfunction is beyond the scope of this review and the reader is referred to a recent review on this topic [198].

It has been shown in several animal $[199,200]$ and human experiments $[180,197,201,202]$ that endothelium-derived nitric oxide is required to maintain the high perfusion rate in the choroid. With respect to the retina the situation is less clear. Most data from in vitro studies indicate that nitric oxide has a role in the regulation of retinal vascular tone [203, 204]. Studies using nitric oxide synthase inhibitors yielded partially conflicting results, either showing no effect on retinal blood flow $[199,205]$ or a decrease of up to $50 \%$ [206].

Recently it has been shown that the response of the human choroidal vasculature to NOS inhibition is blunted in patients with Type I diabetes [197]. Again the mechanism underlying this altered response of ocular vessels in diabetes is still to be explained. Increased NOS activity in STZ-induced diabetic rat retinas compared with retinas of healthy rats has recently been observed [207]. Interestingly, this study also indicates that the $\mathrm{NO}$ generated by inducible NOS contributes to the total NO release in the diabetic retina. This is compatible with the finding that aminoguanidine reverses increased ocular blood flow in STZ-induced diabetic rats [164]. Aminoguanidine has been shown to inhibit NOS activity probably due to its structural similarity to L-arginine [163], but may also act via other mechanisms.

Endothelin. Endothelins are a number of potent vasoactive peptides, which were first identified and characterised by Yanagisawa et al. [208]. Among these peptides endothelin-1, which is produced by the vascular endothelium, is the most potent vasoconstrictive substance known. Endothelins have been seen in isolated samples of several tissues of the eye including the retina and the choroid $[209,210]$. Endothelin-1 induces potent vasoconstrictor effects in isolated ocular arteries [211,212]. The importance of endothelin in the control of retinal, optic disc and choroidal blood flow was also determined by animal [136, 213-215] and human studies [216, 217].

Increased endothelin-1 plasma concentrations were observed in Type I diabetic patients [218] as well as in Type II patients with diabetic retinopathy [219]. More specifically, it has been shown in immunhistochemical studies that endothelin-1 is increased in retinal tissue of STZ-induced diabetic rats [220] and $\mathrm{BB} / \mathrm{W}$ rats [221]. Moreover, gene expression of 
endothelin-1 is augmented in the retina of chronically diabetic $\mathrm{BB} / \mathrm{W}$ rats [222]. In vivo, treatment with $\mathrm{BQ}$ 123, a specific endothelin ${ }_{\mathrm{A}}$ receptor antagonist, prevents the prolongation of mean transit time in the STZ-induced diabetic rat [136]. The effect of endothelin receptor antagonists on ocular complications in experimental diabetes has not yet been studied. An interesting issue is that endothelin- 1 has been suggested as having a role in hyperoxia-induced retinal vasoconstriction [223]. Hence an alteration in the retinal response to hyperoxia as observed in patients with diabetic retinopathy [9] may at least partially be linked to an altered endothelin system in these subjects.

Vascular endothelial growth factor. Vascular endothelial growth factor (VEGF), which has an important role in the development of proliferative retinopathy, has also been assumed to contribute to the retinal perfusion abnormalities observed in diabetes [87]. Specific binding sites for VEGF have been identified on retinal endothelial cells and pericytes [224] and its inhibition has been reported to suppress retinal neovascularisation [225]. In addition, VEGF expression increases in the early stages of diabetic retinopathy [226] and is reduced to basal levels following photocoagulation [227].

\section{The role of pericytes}

The role of pericytes in retinal capillaries has not yet been fully explained, but they are assumed to have a role in the regulation to retinal blood flow [204, 228, 229]. Bovine retinal capillary pericyte contractility is inhibited by high glucose concentrations. This again indicates the importance of glucose plasma concentrations in the regulation of retinal blood flow [230]. Retinal pericyte loss in diabetes was described more than 30 years ago [231], but neither the cause nor the consequence for retinal blood flow regulation has been explained.

Angiotensin. A possible role of the angiotensin-renin system has been proposed based on increased angiotensin converting enzyme levels in diabetic patients [232] and experimentally diabetic animals [233]. The activity of these enzymes seems, however, to be reduced in diabetic rats and angiotensin is probably not involved in the mechanisms underlying reduced $\mathrm{Na}, \mathrm{K}-\mathrm{ATP}$ ase activity in diabetes [234]. Angiotensin binding sites have been found in retinal blood vessels [235] and local infusion of angiotensin II produces retinal vasoconstriction [236]. This is presumably related to the alteration in capillary pericyte contractility induced by angiotensin II [229]. The exact role of the angiotensin-renin system in the regulation of retinal blood flow is still not clear. The perfused rat eye

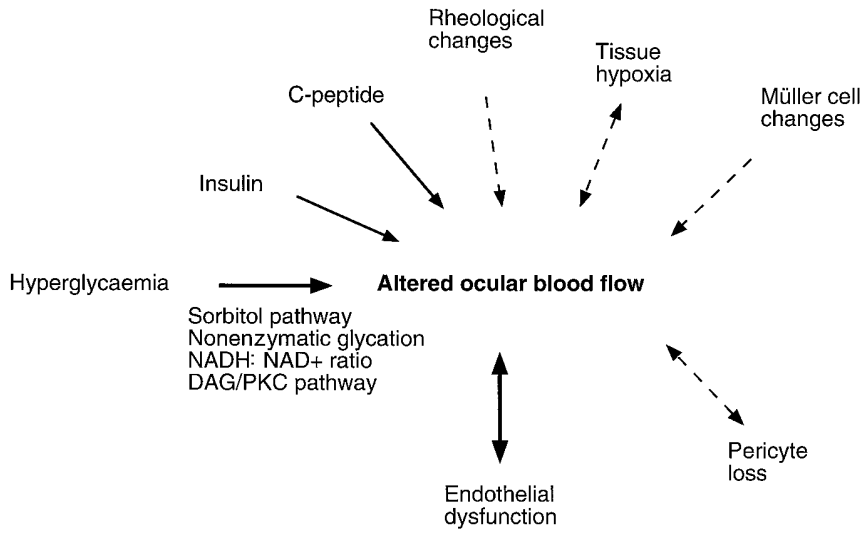

Fig. 1. Pathogenic mechanisms related to altered ocular blood flow in diabetes. Particularly important pathways are highlighted. Dashed lines indicate pathways, which have not yet been directly proven

shows, however, no vascular reactivity to angiotensin II [141], and in the human choroidal vasculature angiotensin II does not appear to have a major role [59].

\section{The role of Müller cell changes}

The Müller cells are the principal glia cells of the retina [237]. Recently it has been shown that not only vascular cells but also Müller cells of the retina are affected in patients with diabetes [238]. With respect to ocular blood flow this is of importance as Müller cells express endothelin [222] as well as NO [237]. The role of Müller cells in the development of ocular perfusion abnormalities and diabetic retinopathy is, however, not yet established and additional investigations in this field are necessary.

\section{Conclusions}

Obviously there is a lot of discrepancy between the various clinical and experimental studies investigating ocular blood flow in diabetes. The variety of techniques used for the investigation of haemodynamics of the eye may certainly account, in part, for this problem. In addition, considerable differences in ocular perfusion may exist between patients with Type I and Type II diabetes, which have not yet been systematically studied. In many cross-sectional studies little attention has been drawn to actual glucose and insulin plasma concentrations (although both may affect ocular blood flow), to metabolic control or to the duration of the disease. There is strong evidence that retinal blood flow is, however, raised in the early stages of diabetes even before the onset of diabetic retinopathy. The reason for this increase in retinal perfusion is most probably coupled to the cellular and intracellular alterations induced by glucose and to en- 
dothelial dysfunction (Fig. 1). In addition, there is evidence that increased retinal blood flow itself is detrimental for the development of diabetic retinopathy. Altered ocular blood flow is therefore a surrogate marker of early diabetic complications. As such it has already been used in a variety of animal studies to screen for drugs with therapeutic potential in the treatment of diabetic retinopathy. This approach should also be exploited in human studies in the near future.

Acknowledgements. The authors thank Professor H.-G. Eichler for many helpful suggestions and Dr. E. Polska for help in the literature search.

\section{References}

1. Frank RN (1995) Diabetic retinopathy. Prog Retina Eye Res 14: 362-392

2. Early treatment diabetic retinopathy study research group (1991) Grading diabetic retinopathy from stereoscopic color fundus photographs-an extension of the modified Airlie House classification. ETDRS report Nr.10. Ophthalmology 98: 786-806

3. Early treatment diabetic retinopathy study research group (1991) Classification of diabetic retinopathy from fluorescein angiograms. ETDRS Report Nr.11. Ophthalmology 98: 807-822

4. Farkas TG, Sylvester V, Archer D (1970) An electron microscopic study of the choriocapillaries and Bruch's membrane in diabetic retinopathy. Trans Ophthalmol Soc UK 90: 657-668

5. Caldwell RB, Fitzgerald MEC (1991) The choriocapillaries in spontaneously diabetic rats. Microvasc Res 42: 229-242

6. Mc Leod DS, Lutty GA (1994) High-resolution histologic analysis of the human choroidal vasculature. Invest Ophthalmol Vis Sci 35: 3799-3811

7. Alm A (1992) Ocular circulation. In: Hart WM (ed) Adler's Physiology of the eye. Mosby, St. Louis, pp 198-227

8. Alm A, Bill A (1973) Ocular and optic nerve blood flow at normal and increased intraocular pressure in monkeys (Macaca irus): a study with radioactively labelled microspheres including flow determinations in brain and some other tissues. Exp Eye Res 15: 15-29

9. Grunwald JE, Riva CE, Petrig BL, Sinclair SH, Brucker AJ (1984) Effect of pure $\mathrm{O}_{2}$-breathing on retinal blood flow in normals and in patients with background diabetic retinopathy. Curr Eye Res 3: 239-241

10. Schmetterer L, Lexer F, Findl O, Graselli U, Eichler HG, Wolzt M (1996) The effect of inhalation of different mixtures of $\mathrm{O} 2$ and $\mathrm{CO} 2$ on ocular fundus pulsations. Exp Eye Res 63: 351-355

11. Riva CE, Sinclair SH, Grunwald JE (1981) Autoregulation of retinal circulation in response to decrease of perfusion pressure. Invest Ophthalmol Vis Sci 21: 34-38

12. Riva CE, Grunwald JE, Petrig BL (1986) Autoregulation of human retinal blood flow. An investigation with laser Doppler velocimetry. Invest Ophthalmol Vis Sci 27: 1706-1712

13. Rassam SMB, Patel V, Kohner EM (1995) The effect of experimental hypertension on retinal vascular autoregulation in humans: a mechanism for the progression of diabetic retinopathy. Exp Physiol 80: 53-68
14. Dumsky MJ, Eriksen JE, Dore CJ, Kohner EM (1996) Autoregulation in the human retinal circulation: assessment using isometric exercise, laser Doppler velocimetry, and computer-assisted image analysis. Microvasc Res 51: 378-392

15. Kiel JW, Shepard AP (1992) Autoregulation of choroidal blood flow in the rabbit. Invest Ophthalmol Vis Sci 33: 2399-2410

16. Riva CE, Titze P, Hero M, Petrig BL (1997) Effect of acute decreases of perfusion pressure on choroidal blood flow in humans. Invest Ophthalmol Vis Sci 38: 1752-1760

17. Harris A, Kagemann L, Cioffi GA (1998) Assessment of human ocular hemodynamics. Surv Ophthalmol 42: 509533

18. Novotny HR, Alvis DL (1961) A method of photographing fluorescence in circulating blood in the human retina. Circulation 24: 82-86

19. Hickam JB, Frayser R (1965) A photographic method for measuring the mean retinal circulation time using fluorescein. Invest Ophthalmol 4: 876-884

20. Preussner PR, Richard G, Darrelmann O, Weber J, Kreissig I (1983) Quantitative measurement of retinal blood flow in human beings by application of digital image-processing methods to television fluorescein angiograms. Graefes Arch Clin Exp Ophthalmol 221: 110-112

21. Wolf S, Jung F, Kiesewetter H, Körber N, Reim M (1989) Video fluorescein angiography: method and clinical application. Graefes Arch Clin Exp Ophthalmol 227: 145-151

22. Bursell SE, Clermont AC, Shiba T, King GL (1992) Evaluating retinal circulation using video fluorescein angiography in control and diabetic rats. Curr Eye Res 11: 287295

23. Wolf S, Arend O, Toonen H, Bertram B, Jung F, Reim M (1991) Retinal capillary blood flow measurement with a scanning laser ophthalmoscope. Ophthalmology 98: 996-1000

24. Tanaka T, Muraoka K, Shimizu K (1991) Fluorescein fundus angiography with scanning laser ophthalmoscope. Visibility of leukocytes and platelets in perifoveal capillaries. Ophthalmology 98: 1824-1829

25. Miyamoto K, Ogura Y, Nishiwaki H et al. (1996) Evaluation of retinal microcirculatory alterations in the GotoKakizaki rat. A spontaneous model of non-insulin-dependent diabetes. Invest Ophthalmol Vis Sci 37: 898-905

26. Lee ET, Rehkopf PG, Warnicki JW, Friberg T, Finegold DN, Cape EG (1997) A new method for assessment of changes in retinal blood flow. Med Eng Phys 19: 125-130

27. Kohner EM (1976) The problems of retinal blood flow in diabetes. Diabetes 25 [Suppl 2] 839-844

28. Zeimer R, Guran T, Shahidi M, Mori MT (1990) Visualization of the retinal microvasculature by targeted dye delivery. Invest Ophthalmol Vis Sci 31: 1459-1465

29. Arend O, Wolf S, Jung F et al. (1991) Retinal microcirculation in patients with diabetes mellitus: dynamic and morphological analysis of perifoveal capillary network. Br J Ophthalmol 75: 514-518

30. Ben-Nun J, Constable IJ (1992) Segmentation of fluorescence in the retinal microcirculation-is it a valid indicator of blood cell flow? Br J Ophthalmol 76: 510

31. Ben-Nun J, Alder V, Thompson D, Constable IJ (1992) Flow patterns of blood cells in the retinal capillaries. Retinal capillary flow patterns. Int Ophthalmol 16: 81-89

32. Ben-Nun J (1996) Comparative flow velocity of erythrocyte and leukocytes in feline retinal capillaries. Invest Ophthalmol Vis Sci 37: 1854-1859

33. Nishiwaki H, Ogura Y, Kimura H, Kiryu J, Miyamoto K, Matsuda N (1996) Visualization and quantitative analysis 
of leukocyte dynamics in retinal microcirculation in rats. Invest Ophthalmol Vis Sci 37: 1341-1347

34. Prünte C, Niesel P (1988) Quantification of choroidal blood-flow parameters using indocyanine green video angiography and statistical picture analysis. Graefes Arch Clin Exp Ophthalmol 236: 55-58

35. Flower RW (1993) Extraction of choriocapillaries hemodynamic data from ICG fluorescence angiograms. Invest Ophthalmol Vis Sci 24: 2720-2729

36. Duijm HFA, Rulo AHF, Astin M, Maepea O, van den Berg TJTP, Greve EL (1996) Study of choroidal blood flow by comparison of SLO fluorescein angiography and microspheres. Exp Eye Res 63: 693-704

37. Matsuda N, Ogura Y, Nishiwaki H et al. (1996) Visualization of leukocyte dynamics in the choroid with indocyanine green. Invest Ophthalmol Vis Sci 37: 2228-2233

38. Asrani S, Zou S, D’Anna S, Goldberg MF, Zeimer R (1996) Noninvasive visualization of blood flow in the choriocapillaries of the rat. Invest Ophthalmol Vis Sci 37: 312-317

39. Riva CE, Ross B, Benedek GB (1972) Laser Doppler measurements of blood flow in capillary tubes and retinal arteries. Invest Ophthalmol Vis Sci 11: 936-944

40. Tanaka T, Riva C, Ben Sira B (1974) Blood velocity measurements in human retinal vessels. Science 186: 830-831

41. Riva CE, Feke GT, Eberli B, Benary V (1979) Bidirectional LDV system for absolute measurement of blood speed in retinal vessels. Appl Opt 18: 2301-2306

42. Riva CE, Grunwald JE, Sinclair SH, Petrig BL (1985) Blood velocity and volumetric flow rate in human retinal vessels. Invest Ophthalmol Vis Sci 26: 1124-1132

43. Feke GT, Tagawa H, Deupree DM, Goger DG, Sebag J, Weiter JJ (1989) Blood flow in the normal human retina. Invest Ophthalmol Vis Sci 30: 58-65

44. Chen HC, Patel V, Wiek J, Rassam SM, Kohner EM (1994) Vessel diameter changes during the cardiac cycle. Eye 8: 97-103

45. Dumsky MJ, Aldington SJ, Dore CJ, Kohner EM (1996) The accurate assessment of changes in retinal vessel diameter using multiple frame electrocardiograph synchronised fundus photography. Curr Eye Res 15: 625-632

46. Formaz F, Riva CE, Geiser M (1997) Diffuse luminance flicker increases retinal vessel diameter. Curr Eye Res 16: 1252-1257

47. Vilser W, Riemer T, Bräuer-Burchardt C et al. (1997) Retinal vessel analyzer (RVA) - a new measuring system for examination of local and temporal vessel behaviour. Invest Ophthalmol Vis Sci 38:S1050

48. Bonner R, Nossal R (1981) Model for laser Doppler measurements of blood flow in tissue. Appl Opt 20: 2097-2107

49. Riva CE, Harino S, Petrig BL, Shonat RD (1992) Laser Doppler flowmetry in the optic nerve. Exp Eye Res 55: 499-506

50. Gherezghiher T, Okubo H, Koss MC (1991) Choroidal and ciliary body blood flow analysis: application of laser Doppler flowmetry in experimental animals. Exp Eye Res 51: 151-156

51. Riva CE, Petrig BL (1995) Choroidal blood flow by laser Doppler flowmetry. Opt Eng 34: 746-752

52. Sebag J, Delori FC, Feke GT et al. (1986) Anterior optic nerve blood flow decreases in clinical neurogenic optic atrophy. Ophthalmology 93: 858-865

53. Michelson G, Schmauss B, Langhans MJ, Harazny J, Groh MJM (1996) Principle, validity, and reliability of scanning laser Doppler flowmetry. J Glaucoma 5: 99-105

54. Van Heuven WAJ, Kiel JW, Elliot WR, Harrison JM, Sponsel WE (1996) Evaluation of the Heidelberg retina flowmeter. Invest Ophthalmol Vis Sci 37 [Suppl] S967
55. Strenn K, Menapace R, Rainer G, Findl O, Wolzt M, Schmetterer L (1997) Reproducibility and sensitivity of scanning laser Doppler flowmetry during graded changes in $\mathrm{pO}_{2}$. Br J Ophthalmol 81: 360-364

56. Lieb WE, Cohen SM, Merton DA, Shields JA, Mitchell DG, Goldberg BB (1991) Color Doppler imaging of the eye and orbit. Technique and normal vascular anatomy. Arch Ophthalmol 109: 527-531

57. Pourcelot L (1976) Diagnostic ultrasound for cerebral vascular diseases. In: Donald I, Levi S (eds) Present and future of diagnostic ultrasound. Kooyker, Rotterdam pp 141-147

58. Hayreh SS, Beach KW (1993) Optic nerve sheath decompression. Discussion. Ophthalmology 1993: 100: 303 305

59. Krejcy K, Wolzt M, Kreuzer C et al. (1997) Characterisation of angiotensin-II effects on cerebral and ocular circulation by noninvasive methods. Br J Clin Pharmacol 43: 501-508

60. Riva CE, Petrig BL (1980) Blue field entoptic phenomenon and blood velocity in the retinal capillaries. $\mathrm{J} \mathrm{Opt}$ Soc Am A 70: 1234-1238

61. Riva CE, Petrig BL (1990) Retinal blood flow: laser Doppler velocimetry and blue field simulation technique. In: Masters B (ed) Noninvasive diagnostic techniques in ophthalmology. Springer, Berlin, Heidelberg, New York, pp 390-409

62. Briers JD, Fercher AF (1982) Retinal blood-flow visualization by means of laser speckle photography. Invest Ophthalmol Vis Sci 22: 255-259

63. Tamaki Y, Araie M, Kawamoto E, Eguchi S, Fuji H (1994) Noncontact, two-dimensional measurement of retinal microcirculation using laser speckle phenomenon. Invest Ophthalmol Vis Sci 35: 3825-3834

64. Tamaki Y, Araie M, Kawamoto E, Eguchi S, Fuji H (1995) Non-contact, two-dimensional measurement of tissue circulation in choroid and optic nerve head using laser speckle phenomenon. Exp Eye Res 60: 373-383

65. Silver DM, Farrell RA (1994) Validity of pulsatile ocular blood flow. Surv Ophthalmol 38 [Suppl] S72-S80

66. Schmetterer L, Lexer F, Unfried CJ, Sattmann H, Fercher AF (1995) Topical fundus pulsation measurement. Opt Eng 34: 711-716

67. Schmetterer L, Wolzt M, Salomon A et al. (1996) Effect of isoproterenol, phenylephrine, and sodium nitroprusside on fundus pulsations in healthy volunteers. Br J Ophthalmol 80: 217-223

68. Schmetterer L, Dallinger S, Findl O et al.(1998) Noninvasive investigations of the normal ocular circulation. Invest Ophthalmol Vis Sci 39: 1210-1220

69. Krakau CE (1995) A model of pulsatile and steady ocular blood flow. Graefes Arch Clin Exp Ophthalmol 233: 112-118

70. Langham ME, Farrell RA, O'Brien V, Silver DM, Schilder P (1989) Blood flow in the human eye. Acta Ophthalmol [Suppl 191] 9-13

71. Alm A, Tornquist P, Stjernschatz J (1977) Radioactively labelled microspheres in regional ocular blood flow determinations. Bibl Anat 16: 24-29

72. Kiel JW (1994) Choroidal myogenic autoregulation and intraocular pressure. Exp Eye Res 58: 529-543

73. Orgül S, Cioffi GA, Bacon DR, Bhandari A, van Buskirk EM (1996) Measurement of optic nerve blood flow with nonradioactive coloured microspheres in rabbits. Microvasc Res 51: 175-186

74. Butt Z, O'Brien C (1995) Reproducibility of pulsatile ocular blood flow measurements. J Glaucoma 4: 214-218 
75. Harris A, Williamson TH, Martin BJ et al. (1995) Test/retest reproducibility of color Doppler imaging assessment of blood flow velocity in orbital vessels. J Glaucoma 4: 281-286

76. Duijm HFA, Rulo AHF, Astin M, Maepea O, van den Berg TJTP, Greve EL (1997) Analysis of variance of microspheres blood flow measurements in rabbits. Exp Eye Res 64: 545-551

77. Nicolela MT, Hnik P, Schulzer M, Drance SM (1997) Reproducibility of retinal and optic nerve head blood flow measurements with scanning laser Doppler flowmetry. J Glaucoma 6: 157-164

78. Joos KM, Pillunat LE, Knighton RW, Anderson DR, Feuer WJ (1997) Reproducibility of laser Doppler flowmetry in the human optic nerve head. J Glaucoma 6: 212-216

79. Schmetterer L, Strenn K, Findl O et al. (1997) Effects of antiglaucoma drugs on ocular hemodynamics in healthy volunteers. Clin Pharmacol Ther 61: 583-595

80. Kohner EM, Hamilton AM, Saunders SJ, Sutcliffe BA, Bulpitt CJ (1975) The retinal blood flow in diabetes. Diabetologia 11: 27-33

81. Cunha Vaz JG, Fonscera JR, Abreu JF (1978) Vitreous fluorophotometry and retinal blood flow studies in proliferative retinopathy. Graefes Arch Clin Exp Ophthalmol 207: 71-76

82. Cunha Vaz JG, Fonscera JR, de Abreu JRF, Lima JJP (1978) Studies on retinal blood flow. Arch Ophthalmol 96: 809-811

83. Blair NP, Feke GT, Morales-Stoppello J et al. (1982) Prolongation of the retinal mean circulation time in diabetes. Arch Ophthalmol 100: 764-768

84. Yoshida A, Feke GT, Morales-Stoppello J, Collas GD, Goger DG, Mc Meel JW (1983) Retinal blood flow alterations during progression of diabetic retinopathy. Arch Ophthalmol 101: 225-227

85. Bertram B, Wolf S, Fiehöfer S, Schulte K, Arend O, Reim M (1991) Retinal circulation times in diabetes mellitus type 1. Br J Ophthalmol 75: 462-465

86. Bursell SE, Clermont AC, Kinsley BT, Simonson DC, Aiello LM, Wolpert HA (1996) Retinal blood flow changes in patients with insulin-dependent diabetes mellitus and no diabetic retinopathy. Invest Ophthalmol Vis Sci 37: 886-897

87. Clermont AC, Aiello LP, Mori F, Aiello LM, Bursell SE (1997) Vascular endothelial growth factor and severity of nonproliferative diabetic retinopathy mediate retinal hemodynamics in vivo: a potential role for vascular endothelial growth factor in the progression of nonproliferative diabetic retinopathy. Am J Ophthalmol 124: 433-446

88. Chung TW, Liu AG, Yu JH (1993) Increased red cell rigidity might affect retinal capillary blood flow velocity and oxygen transport efficiency in type II diabetes. Diabetes Res 23: 75-82

89. Arend O, Wolf S, Remky A et al. (1994) Perifoveal microcirculation with non-insulin-dependent diabetes mellitus. Graefes Arch Clin Exp Ophthalmol 232: 225-231

90. Arend O, Wolf S, Harris A, Reim M (1995) The relationship of macular microcirculation to visual acuity in diabetic patients. Arch Ophthalmol 113: 610-614

91. Arend O, Remky A, Evans D, Stüber R, Harris A (1997) Contrast sensitivity loss is coupled with capillary dropout in patients with diabetes. Invest Ophthalmol Vis Sci 38: 1819-1824

92. Feke GT, Tagawa H, Yoshida A et al. (1985) Retinal circulatory changes related to retinopathy progression in insulin-dependent diabetes mellitus. Ophthalmology 92: $1517-1522$
93. Grunwald JE, Riva CE, Sinclair SH, Brucker AJ, Petrig BL (1986) Laser Doppler velocimetry study of retinal circulation in diabetes mellitus. Arch Ophthalmol 104: 991-996

94. Grunwald JE, Riva CE, Baine J, Brucker AJ (1992) Total retinal volumetric blood flow rate in diabetic patients with poor glycemic control. Invest Ophthalmol Vis Sci 33: $356-363$

95. Patel V, Rassam S, Newsom R, Wiek J, Kohner E (1992) Retinal blood flow in diabetic retinopathy. BMJ 305: 678-683

96. Feke GT, Buzney SM, Ogasawara H et al. (1994) Retinal circulatory abnormalities in type 1 diabetes. Invest Ophthalmol Vis Sci 35: 2968-2975

97. Falck A, Laatikainen L (1995) Retinal vasodilation and hyperglycemia in diabetic children and adolescents. Acta Ophthalmol 73: 119-124

98. Grunwald JE, Brucker AJ, Grunwald SE, Riva CE (1993) Retinal hemodynamics in proliferative diabetic retinopathy. Invest Ophthalmol Vis Sci 34: 66-71

99. Konno S, Feke GT, Yoshida A, Fujio N, Goger D, Buzney SM (1996) Retinal blood flow changes in type I diabetes. A long-term follow up study. Invest Ophthalmol Vis Sci 37: $1140-1148$

100. Grunwald JE, Bursell SE (1996) Hemodynamic changes as early markers of diabetic retinopathy. Cur Opin Endocrinol Diabetes 3: 298-306

101. Grunwald JE, DuPont J, Riva CE (1996) Retinal hemodynamics in patients with early diabetes mellitus. Br J Ophthalmol 80: 327-331

102. Tamaki Y, Nagahara M, Aymashita H, Kikuchi M (1993) Blood velocity in the ophthalmic artery determined by color Doppler imaging in normal subjects and diabetics. Jpn J Ophthalmol 37: 385-392

103. Mendivil A, Cuartero V, Mendivil MP (1995) Ocular blood flow velocities in patients with proliferative diabetic retinopathy and healthy volunteers: a prospective study. Br J Ophthalmol 79: 413-416

104. Goebel W, Lieb WE, Ho A, Sergott RC, Farhoumand R, Grehn E (1995) Color Doppler imaging: a new technique to assess orbital blood flow in patients with diabetic retinopathy. Invest Ophthalmol Vis Sci 36: 864-870

105. Kawagishi T, Nishizawa Y, Emoto M et al. (1995) Impaired retinal artery blood flow in IDDM patients before clinical manifestations of diabetic retinopathy. Diabetes Care 18: 1544-1549

106. Fallon TJ, Chowienczyk P, Kohner EM (1986) Measurement of retinal blood flow in diabetes by the blue-light entoptic phenomenon. Br J Ophthalmol 70: 43-46

107. Rimmer T, Fallon TJ, Kohner EM (1989) Long term follow-up of retinal blood flow in diabetes using the blue field light entoptic phenomenon. Br $\mathrm{J}$ Ophthalmol 73: $1-5$

108. Sinclair SH (1991) Macular retinal capillary hemodynamics in diabetic patients. Ophthalmology 98: 1580-1586

109. Langham ME, Grebe R, Hopkins S, Marcus S, Sebag M (1991) Choroidal blood flow in diabetic retinopathy. Exp Eye Res 52: 167-173

110. Becker P, Schmidt KG, von Rückmann A, Hammes HP, Kemkes-Matthes B, Pillunat LE (1997) Ocular pulse amplitude in diabetic patients. Invest Ophthalmol Vis Sci 38:S773

111. MacKinnon JR, O'Brien C, Swa K, Aspinall P, Butt Z, Cameron D (1997) Pulsatile ocular blood flow in untreated diabetic retinopathy. Acta Ophthalmol 75: 661-664

112. Schmetterer L, Salomon A, Rheinberger A, Unfried C, Lexer F, Wolzt M (1997) Fundus pulsation measurement 
in diabetic retinopathy. Graefes Arch Clin Exp Ophthalmol 235: 283-287

113. Schmetterer L, Findl O, Strenn K et al. (1997) Ocular and systemic reactivity to isoprenaline in patients with insulindependent diabetes mellitus. Eur J Clin Invest 27: 750-754

114. Bertram B, Wolf S, Arend O, Schulte K, Reim M (1992) Retinale Durchblutung und aktueller Blutzuckerwert bei Retinopathia diabetica. Klin Monatsbl Augenheilkd 200: 654-657

115. Diabetes Control and Complications Trial Research Group (1993) The effect of intensive treatment of diabetes on the development and progression of long-term complications in insulin-dependent diabetes mellitus. $\mathrm{N}$ Engl J Med 329: 977-986

116. Waldhäusl W, Freyler H, Bratusch-Marrain P, Vierhapper H, Bruneder H (1983) Continuous subcutaneous insulin infusion: long-term treatment in an unselected group of insulin-dependent diabetics. Dtsch Med Wochenschr 108: 570-577

117. Grunwald JE, Brucker AJ, Schwartz SS et al. (1990) Diabetic glycemic control and retinal blood flow. Diabetes 39: 602-607

118. Grunwald JE, Brucker AJ, Braunstein SN et al. (1994) Strict metabolic control and retinal blood flow in diabetes mellitus. Br J Ophthalmol 78: 598-604

119. Grunwald JE, Riva CE, Petrig BL et al. (1995) Strict control of glycaemia: effects on blood flow in the large retinal vessels and in the macular microcirculation. Br J Ophthalmol 79: 735-741

120. Patel V, Rassam SMB, Chen HC, Kohner EM (1994) Oxygen reactivity in diabetes mellitus: effect of hypertension and hyperglycaemia. Clin Sci 86: 689-695

121. Evans DW, Harris A, Danis RP, Arend O, Martin BJ (1997) Altered retrobulbar vascular reactivity in early diabetic retinopathy. Br J Ophthalmol 81: 279-282

122. Fallon TJ, Maxwell DL, Kohner EM (1987) Autoregulation of retinal blood flow in diabetic retinopathy measured by the blue-light entoptic technique. Ophthalmology $94: 1410-1415$

123. Sinclair SH, Grunwald JE, Riva CE, Braunstein SH, Nichols CW, Schwartz SS (1982) Retinal vascular autoregulation in diabetes mellitus. Ophthalmology 89: 748-750

124. Feke GT, Green GJ, Goger DG, Mc Meel JW (1982) Laser Doppler measurements of the effect of panretinal photocoagulation on retinal blood flow. Ophthalmology 89: $757-762$

125. Grunwald JE, Brucker AJ, Petrig BL, Riva CE (1989) Retinal blood flow regulation and the clinical response to panretinal photocoagulation in proliferative diabetic retinopathy. Ophthalmology 96: 1518-1522

126. Ostwald B, Vilser W, Ostwald H et al. (1985) Measurement of flow-physiologic parameters of retinal blood circulation in type 1 and 2 diabetics before and after photocoagulation. Graefes Arch Clin Exp Ophthalmol 223: 154-157

127. Remky A, Arend O, Beausencourt E, Elsner AE, Bertram B (1996) Retinale Gefäße vor und nach Photokoagulation bei diabetischer Retinopathie. Klin Monatsbl Augenheilkd 209: 79-83

128. Fujio N, Feke GT, Goger DG, McMeel JW (1994) Regional retinal blood flow reduction following half fundus photocoagulation treatment. $\mathrm{Br} \mathrm{J}$ Ophthalmol 78: 335-338

129. Bertram B, Arend O, Moritz A, Wolf S, Remky A (1996) Retinale Hämodynamik bei diabetischer Retinopathie vor und nach Laserkoagulation. Klin Monatsbl Augenheilkd 208: 152-156
130. Stefansson E, Machemer R, deJuan E, McCuen BW, Peterson J (1992) Retinal oxygenation and laser treatment in patients with diabetic retinopathy. Am J Ophthalmol 113: $36-38$

131. Gottfredsdottir MS, Stefansson E, Jonasson F, Gislason I (1993) Retinal vasoconstriction after laser treatment for diabetic macular edema. Am J Ophthalmol 115: 64-67

132. Hessemer V, Schmidt KG (1997) Influence of panretinal photocoagulation on the ocular pulse curve. Am J Ophthalmol 123: 748-752

133. Landers MB, Stefansson E, Wolbarsht ML (1982) Panretinal photocoagulation and retinal oxygenation. Retina 2: 167-175

134. Clermont AC, Brittis M, Shiba T et al. (1994) Normalization of retinal blood flow in diabetic rats with primary intervention using insulin pumps. Invest Ophthalmol Vis Sci 35: 981-990

135. Takagi C, King GL, Clermont AC, Cummins DR, Takagi H, Bursell SE (1995) Reversal of abnormal retinal hemodynamics in diabetic rats by acarbose, an $\alpha$-glucosidase inhibitor. Curr Eye Res 14: 741-749

136. Takagi C, Bursell SE, Lin YW et al. (1996) Regulation of retinal hemodynamics in diabetic rats by increased expression and action of endothelin-1. Invest Ophthalmol Vis Sci 37: 2504-2518

137. Cringle SJ, Yu DY, Alder VA, Su EN (1993) Retinal blood flow by hydrogen clearance polarography in streptozotocin-induced diabetic rat. Invest Ophthalmol Vis Sci 34: 1716-1721

138. Pugliese G, Tilton RG, Speedy A et al (1989) Effects of very mild versus overt diabetes on vascular hemodynamics and barrier function in rats. Diabetologia 32: 845-857

139. Tilton RG, Chang K, Pugliese G et al. (1989) Prevention of hemodynamic and vascular albumin filtration changes in diabetic rats by aldose reductase inhibitors. Diabetes 37: $1258-1270$

140. Sutera SP, Chang K, Marvel J, Williamson JR (1992) Concurrent increases in regional hematocrit and blood flow in diabetic rats: prevention by sorbinil. Am J Physiol 263:H945-H950

141. Su EN, Yu DY, Alder VA, Yu PK, Cringle JS (1995) Altered vasoactivity in the early diabetic eye: measured in the isolated perfused rat eye. Invest Ophthalmol Vis Sci 61: 699-711

142. Small KW, Stefansson E, Hatchell DL (1987) Retinal blood flow in normal and diabetic dogs. Invest Ophthalmol Vis Sci 28: 672-675

143. Chandra S, Ernest JT, Goldstick TK (1982) Effect of photocoagulation on ocular blood flow. Invest Ophthalmol Vis Sci 22: 783-787

144. Hiroshiba N, Ogura Y, Nishiwaki H, Miyamoto K, Honda $Y$ (1998) Alterations of retinal microcirculation in response to scatter photocoagulation. Invest Ophthalmol Vis Sci 39: 769-776

145. Engerman RL, Kern TS (1987) Progression of incipient diabetic retinopathy during good glycemic control. Diabetes 36: 808-812

146. Engerman RL (1989) Pathogenesis of diabetic retinopathy. Diabetes 38: 1203-1206

147. Atherton A, Hill DW, Keen H, Young S, Edwards EJ (1980) The effect of acute hyperglycaemia on the retinal circulation of the normal cat. Diabetologia 18: 233-237

148. Ernest JT, Goldstick TK, Engerman RL (1983) Hyperglycaemia impairs retinal oxygen autoregulation in normal and diabetic dogs. Invest Ophthalmol Vis Sci 24: 985-989

149. Sullivan PM, Davies GE, Caldwell G, Morris AC, Kohner EM (1990) Retinal blood flow during hyperglycemia. A 
laser Doppler velocimetry study. Invest Ophthalmol Vis Sci 31: 2041-2045

150. Hasan KS, Santiago JV, Williamson JR (1993) Acute hyperglycemia-induced increases in regional blood flow are prevented by pyruvate and by tolrestat. Diabetes 42 [Suppl 1] 189A

151. Caldwell G, Davies EG, Sullivan PM, Morris AHC, Kohner EM (1990) A laser Doppler velocimetry study of the effect of hypoglycaemia on retinal blood flow in the minipig. Diabetologia 33: 262-265

152. Grunwald JE, Riva CE, Martin DB, Quint AR, Epstein PA (1987) Effect of an insulin-induced decrease in blood glucose on the human diabetic retinal circulation. Ophthalmology 94: 1614-1620

153. Greene DA, Lattimer SA, Sima AA (1987) Sorbitol, phosphoinostides and sodium-potassium-ATPase in the pathogenesis of diabetic complications. N Engl J Med 329: 977-986

154. Frank RN, Keirn RJ, Kennedy A, Frank KW (1983) Galactose-induced retinal capillary basement membrane thickening: prevention by sorbinil. Invest Ophthalmol Vis Sci 24: 1519-1524

155. Engerman RL, Kern TS (1984) Experimental galactosemia produces diabetic-like retinopathy. Diabetes 33: 97-100

156. Robsion WG, Tillis TN, Laver N, Kinoshita JH (1990) Diabetes-related histopathologies of the rat retina prevented with an aldose reductase inhibitor. Exp Eye Res 50: 355-366

157. Sorbinil Retinopathy Trial Research Group (1990) A randomized trial of sorbinil, an aldose reductase inhibitor, in diabetic retinopathy. Arch Ophthalmol 108: 1234-1244

158. Tilton RG, Chang K, Weigel C et al. (1988) Increased ocular blood flow and 125I-albumin permeation in galactosefed rats: inhibition by sorbinil. Invest Ophthalmol Vis Sci 29: 861-868

159. Bunn HF, Gabbay KH, Gallop PM (1978) The glycosylation of hemoglobin: relevance to diabetes mellitus. Science 200: 21-27

160. Monnier VM, Vishwanath V, Frank KE, Elmets CA, Dauchot P, Kohn PR (1986) Relation between complications of type I diabetes mellitus and collagen-linked fluorescence. N Engl J Med 314: 403-408

161. Hammes HP, Martin S, Federlin K, Geisen K, Brownlee M (1991) Aminoguanidine treatment inhibits the development of experimental diabetic retinopathy. Proc Nat Acad Sci 88: $11555-11558$

162. Soulis-Liparota T, Cooper M, Papazoglou D, Clarke B, Jerums G (1991) Retardation by aminoguanidine of development of albuminuria, mesangial expansion, and tissue fluorescence in streptozotocin-induced diabetic rats. Diabetes 40: 1328-1334

163. Corbett JA, Tilton RG, Chang K et al. (1992) Aminoguanidine, a novel inhibitor of nitric oxide formation, prevents diabetic vascular dysfunction. Diabetes 41: 552-556

164. Tilton RG, Chang K, Hasan KS et al. (1993) Prevention of diabetic vascular dysfunction by guanidines. Inhibition of nitric oxide synthase versus advanced glycation end-product formation. Diabetes 42: 221-232

165. Williamson JR, Chang K, Frangos M et al. (1993) Hyperglycemic pseudohypoxia and diabetic complications. Diabetes 42: 801-813

166. Ido Y, Kilo C, Williamson JR (1997) Cytosolic NADH/ $\mathrm{NAD}^{+}$, free radicals, and vascular dysfunction in early diabetes mellitus. Diabetologia 40: S115-S117

167. Van den Enden MK, Nyengaard JR, Ostrow E, Burgan JH, Williamson JR (1995) Elevated glucose levels in- crease retinal glycolysis and sorbitol pathway metabolism. Implications for diabetic retinopathy. Invest Ophthalmol Vis Sci 36: 1675-1685

168. Winkler BS, Arnold MJ, Brassell MA, Sliter DR (1997) Glucose dependence of glycolysis, hexose monophosphate shunt activity, energy status and the polyol pathway in retinas isolated from normal (nondiabetic) rats. Invest Ophthalmol Vis Sci 38: 62-71

169. Williamson JR, Ido Y (1998) Understanding retinal cytosolic reductive stress. Invest Ophthalmol Vis Sci 39: 1295-1296

170. Ishii H, Koya D, King GL (1998) Protein kinase C activation and its role in the development of vascular complications in diabetes mellitus. J Mol Med 76: 21-31

171. Shiba T, Inoguchi T, Sportsman JR, Heath WF, Bursell SE, King GL (1993) Correlation of diacyglycerol level and protein kinase $\mathrm{C}$ activity in rat retina to retinal circulation. Am J Physiol 265:E783-E793

172. Kunisaki M, Bursell SE, Clermont AC et al. (1995) Vitamin E prevents diabetes-induced abnormal retinal blood flow via the diacylglycerol-protein kinase $\mathrm{C}$ pathway. Am J Physiol 269:E239-E246

173. Clermont AC, Aiello LP, Aiello LM et al. (1998) Vitamin E normalized retinal blood flow in diabetic patients minimal diabetic retinopathy: results of a double masked crossover clinical trial. Invest Ophthalmol Vis Sci 39:S1000

174. Ishii H, Jirousek MR, Koya D et al. (1996) Amelioration of vascular dysfunction in diabetic rats by an oral PKC $\beta$ inhibitor. Science 272: 728-731

175. Birch KA, Heath WF, Hermeling RN et al. (1996) LY290181, an inhibitor of diabetes-induced vascular dysfunction, blocks protein kinase C-stimulated transcriptional activation through inhibition of transcription factor binding to a phorbol response element. Diabetes 45: 642-650

176. Klein R, Moss SE, Klein BE, Davis MD, DeMets DL (1990) Wisconsin Epidemiologic Study of Diabetic Retinopathy. XII. Relationship of C-peptide and diabetic retinopathy. Diabetes 39: 1445-1450

177. Baron AD (1994) Hemodynamic actions of insulin. Am J Physiol 267:E187-E202

178. Steinberg HO, Brechtel G, Johnson A, Fineberg N, Baron AD (1994) Insulin-mediated skeletal muscle vasodilation is nitric oxide dependent. A novel action of insulin to increase nitric oxide release. J Clin Invest 94: 1172-1179

179. Han SZ, Ouchi Y, Karaki H, Orimo H (1995) Inhibitory effects of insulin on cytostolic $\mathrm{Ca} 2+$ level and contraction in the aorta. Endothelium-dependent and-independent mechanisms. Circ Res 77: 673-678

180. Schmetterer L, Müller M, Fasching P et al. (1997) Renal and ocular hemodynamic effects of insulin. Diabetes 46: 1868-1874

181. Su EN, Yu DY, Alder VA, Cringle JS, Yu PK (1996) Direct vasodilatory effect of insulin on isolated retinal arterioles. Invest Ophthalmol Vis Sci 37: 2634-2644

182. Klein R, Klein BEK, Moss SE (1995) The Wisconsin epidemiologic study of diabetic retinopathy. XVI. The relationship of C-peptide to the incidence and progression of diabetic retinopathy. Diabetes 44: 796-801

183. Ido Y, Vindigni A, Chang K et al. (1997) Prevention of vascular and neural dysfunction in diabetic rats by C-peptide. Science 277: 563-566

184. Henkind P (1978) Ocular neovascularizations. Am J Ophthalmol 85: 287-301

185. Harris A, Arend O, Danis RP, Evans D, Wolf S, Martin BJ (1996) Hyperoxia improves contrast sensitivity in early diabetic retinopathy. Br J Ophthalmol 80: 209-213 
186. Alder VA, Su EN, Yu DY, Cringle SJ, Yu PK (1997) Diabetic retinopathy: early functional changes. Clin Exp Pharmacol Physiol 24: 785-788

187. McMillan DE (1976) Plasma protein changes, blood viscosity, and diabetic microangiopathy. Diabetes 25 [Suppl 2] 858-864

188. Kelly LW, Barden CA, Tiedeman JS, Hatchell DL (1993) Alterations in viscosity and filterability of whole blood and blood cell subpopulations in diabetic cats. Exp Eye Res 56: 341-347

189. Kohner EM, Patel V, Rassam SMB (1995) Role of blood flow and impaired autoregulation in the pathogenesis of diabetic retinopathy. Diabetes 44: 603-607

190. Knowler WC, Bennett PH, Ballintine EJ (1980) Increased incidence of retinopathy in diabetics with elevated blood pressure. A six-year follow-up study in Pima Indians. N Engl J Med 302: 645-650

191. Moncada S, Radomski MW, Palmer RM (1988) Endothelium-derived relaxing factor. Identification as nitric oxide and role in the control of vascular tone and platelet function. Biochem Pharmacol 37: 2495-2501

192. Kamata K, Miyata N, Kasuya Y (1989) Impairment of endothelium-dependent relaxation and changes in levels of cyclic GMP in aorta from streptozotocin-induced diabetic rats. Br J Pharmacol 97: 614-618

193. McNamee CJ, Kappagoda CT, Kunjara R, Russell JC (1994) Defective endothelium-dependent relaxation in the JCR:LA-corpulent rat. Circ Res 74: 1126-1132

194. Sexl V, Mancusi G, Raberger G, Schütz W (1995) Age-related changes in vascular rigidity in genetically diabetic rats. Pharmacology 50: 238-246

195. McVeigh GE, Brennan GM, Johnston GD et al. (1992) Impaired endothelium-dependent and independent vasodilation in patients with type 2 (non-insulin-dependent) diabetes mellitus. Diabetologia 35: 771-776

196. Calver A, Collier J, Vallance P (1992) Inhibition and stimulation of nitric oxide synthesis in the human forearm arterial bed of patients with insulin-dependent diabetes. J Clin Invest 90: 2548-2554

197. Schmetterer L, Findl O, Fasching P et al. (1997) Nitric oxide and ocular blood flow in patients with IDDM. Diabetes 46: 653-658

198. Pieper GM (1998) Review of alterations in endothelial nitric oxide productions in diabetes. Protective role of arginine on endothelial dysfunction. Hypertension 31: $1047-1060$

199. Deussen A, Sonntag M, Vogel R (1993) L-arginine derived nitric oxide: a major determinant of uveal blood flow. Exp Eye Res 57: 129-134

200. Mann RM, Riva CE, Stone RA, Barnes GE, Cranstoun SD (1995) Nitric oxide and choroidal blood flow regulation. Invest Ophthalmol Vis Sci 36: 925-930

201. Schmetterer L, Krejcy K, Kastner J et al. (1997) The effect of nitric oxide synthase inhibition on ocular fundus pulsations in man. Exp Eye Res 64: 305-312

202. Schmetterer L, Findl O, Strenn K et al. (1997) Role of NO in the $\mathrm{O}_{2}$ and $\mathrm{CO}_{2}$ responsiveness of cerebral and ocular circulation in humans. Am J Physiol 273:R2005-R2112

203. Benedito S, Prieto D, Nielsen PJ, Berg Nyborg NC (1991) Histamine induces endothelium-dependent relaxation of bovine retinal arteries. Invest Ophthalmol Vis Sci 32: 32-38

204. Haefliger IO, Zschauer A, Anderson DR (1994) Relaxation of retinal pericyte contractile tone through the nitric oxide-cyclic guanosine monophosphate pathway. Invest Ophthalmol Vis Sci 35: 991-997

205. Ostwald P, Goldstein IM, Pachnanda A, Roth S (1995) Effect of nitric oxide synthase inhibition on blood flow after retinal ischemia in cats. Invest Ophthalmol Vis Sci 36: 2396-2403

206. Seligsohn EE, Bill A (1993) Effects of NG-nitro-L-arginine methyl ester on the cardiovascular system of the anaesthetised rabbit and on the cardiovascular response to thyrotropin-releasing hormone. $\mathrm{Br} \mathrm{J}$ Pharmacol 109: $1219-1225$

207. Do Carmo A, Lopes C, Santos M, Proenca R, Cunha Vaz J, Carvalho AP (1998) Nitric oxide synthase activity and L-arginine metabolism in the retinas from streptozotocin-induced diabetic rats. Gen Pharmacol 30: 319-324

208. Yanagisawa M, Kurihara H, Kimura S et al. (1988) A novel potent vasoconstrictor peptide produced by vascular endothelial cells. Nature 332: 411-415

209. Stitt AW, Chakravarthy U, Gardiner TA, Archer DB (1996) Endothelin-like immunoreactivity and receptor binding in the choroid and retina. Curr Eye Res 15: 111-117

210. Wollensak G, Schaefer HE, Ihling C (1998) An immunhistochemical study of endothelin-1 in the human eye. Curr Eye Res 17: 1541-1545

211. Yao K, Tschudi M, Flammer J, Lüscher TF (1991) Endothelium-dependent regulation of vascular tone of the porcine ophthalmic artery. Invest Ophthalmol Vis Sci 32: 1791-1798

212. Haefliger IO, Flammer J, Lüscher TF (1992) Nitric oxide and endothelin-1 are important regulators of human ophthalmic artery. Invest Ophthalmol Vis Sci 33: 2340-2343

213. Granstam E, Wang L, Bill A (1992) Ocular effects of endothelin-1 in the cat. Curr Eye Res 11: 325-332

214. Meyer P, Flammer J, Lüscher TF (1993) Endothelium-dependent regulation of the ophthalmic microcirculation in the perfused porcine eye: role of nitric oxide and endothelins. Invest Ophthalmol Vis Sci 34: 3614-3621

215. Cioffi GA, Orgül S, Onda E, Bacon DR, van Buskirk EM (1995) An in vivo model of chronic optic nerve ischemia: the dose-dependent effects of endothelin-1 on optic nerve microvasculature. Curr Eye Res 14: 1147-1153

216. Schmetterer L, Findl O, Strenn K et al. (1997) Effects of endothelin-1 (ET-1) on ocular hemodynamics. Curr Eye Res 16: 687-692

217. Strenn K, Matulla B, Wolzt M et al. (1998) Reversal of endothelin-1 induced ocular hemodynamic effects by lowdose nifedipine in humans. Clin Pharmacol Ther 63: 54-63

218. Takahashi K, Ghatei MY, Lam HC, O'Halloran DJ, Bloom SR (1990) Elevated plasma endothelin in patients with diabetes mellitus. Diabetologia 33: 306-310

219. Letizia C, Iannacone A, Cerci S et al. (1997) Circulating endothelin-1 in non-insulin-dependent diabetic patients with retinopathy. Horm Metab Res 29: 247-251

220. Chakravarthy U, Hayes RG, Stitt AW, Douglas A (1997) Endothelin expression in ocular tissues of diabetic and insulin-treated rats. Invest Ophthalmol Vis Sci 38; 2144-2151

221. Chakrabarti S, Sima AA (1997) Endothelin-1 and endothelin-3-like immunoreactivity in the eyes of diabetic and non-diabetic $\mathrm{BB} / \mathrm{W}$ rats. Diabetes Res Clin Pract 37: 109-120

222. Chakrabarti S, Gan XT, Merry A, Karmazyn M, Sima AA (1998) Augmented retinal endothelin-1, endothelin-3, endothelin $_{\mathrm{A}}$ and endothelin $\mathrm{B}_{\mathrm{B}}$ gene expression in chronic diabetes. Curr Eye Res 17: 301-307

223. Takagi C, King GL, Takagi H, Lin YE, Clermont AC, Bursell SE (1996) Endothelin-1 action via endothelin receptors is a primary mechanism modulating retinal circulatory response to hyperoxia. Invest Ophthalmol Vis Sci 37: 2099-2109 
224. Takagi C, King GL, Aiello LP (1996) Identification and characterization of vascular endothelial growth factor receptor (Flt) in bovine retinal pericytes. Diabetes 45: 1016-1023

225. Aiello LP, Pierce EA, Foley ED et al. (1995) Suppression of retinal neovascularization in vivo by inhibition of vascular endothelial growth factor (VEGF) using soluble VEGF-receptor chimeric proteins. Proc Natl Acad Sci 92: 10457-10461

226. Amin RH, Frank RN, Kennedy A, Eliott D, Puklin JE, Abrams GW (1997) Vascular endothelial growth factor is present in glial cells of the retina and optic nerve of human subjects with nonproliferative diabetic retinopathy. Invest Ophthalmol Vis Sci 38: 36-47

227. Boulton M, Foreman D, Williams G, Mc Leod D (1998) VEGF localisation in diabetic retinopathy. $\mathrm{Br} \mathrm{J}$ Ophthalmol 82: 561-568

228. Chakravarthy U, Gardiner TA, Anderson P. Archer DB, Trimble ER (1992) The effect of endothelin-1 on the retinal microvascular pericyte. Microvasc Res 43: 241-254

229. Matsugi T, Chen Q, Anderson DR (1997) Contractile responses of cultured bovine retinal pericytes to angiotensin II. Arch Ophthalmol 115: 1281-1285

230. Gillies MC, Su T (1993) High glucose inhibits retinal capillary pericyte contractility in vitro. Invest Ophthalmol Vis Sci 34: 3396-3401
231. Kuwabara T, Cogan DG (1963) Retinal vascular patterns. VI. Mural cells of the retinal capillaries. Arch Ophthalmol 69: 492-502

232. Lieberman J, Sastre A (1980) Serum angiotensin-converting enzyme: elevations in diabetes mellitus. Ann Intern Med. 93: 825-826

233. Ottlecz A, Bensaoula T (1996) Captopril ameliorates the decreased NA,$+ \mathrm{K}(+)$-ATPase activity in the retina of streptozotocin-induced diabetic rats. Invest Ophthalmol Vis Sci 37: 1633-1641

234. Ottlecz A, Bensaoula T, Eichberg J, Peterson RG (1996) Angiotensin-converting enzyme activity in retinas of streptozotocin-induced and zucker diabetic rats. The effect of angiotensin II on $\mathrm{NA}^{+}, \mathrm{K}^{+}$-ATPase activity. Invest Ophthalmol Vis Sci 37: 2157-2164

235. Ferrari-Dileo G, Davis EB, Anderson DR (1987) Angiotensin binding sites in bovine and human retinal blood vessels. Invest Ophthalmol Vis Sci 28: 1747-1751

236. Rockwood EJ, Fantes F, Davies EB, Anderson DR (1987) The response of retinal vasculature to angiotensin. Invest Ophthalmol Vis Sci 28: 676-682

237. Newman E, Reichenbach A (1996) The Muller cell: a functional element of the retina. Trends Neurosci 19: 307-312

238. Mizutani M, Gerhardinger C, Lorenzi M (1998) Müller cell changes in human diabetic retinopathy. Diabetes 47: 445-449 